\title{
HARD RULES OR A HANDSHAKE: \\ THE ROLE OF SOFT LAW IN RULES-BASED GOVERNANCE \\ EXAMINING THE GOVERNANCE STRUCTURE OF \\ FINANCIAL MARKETS \\ IN EAST ASIA
}

\author{
By \\ Jody Marie Lundrigan, B.P.A.P.M.
}

\begin{abstract}
A thesis submitted to
the Faculty of Graduate Studies and Research

in partial fulfillment of

the requirements for the degree of
\end{abstract}

\author{
Master of Arts \\ Legal Studies \\ Department of Law \\ Carleton University \\ Ottawa, Ontario \\ March 1, 2007 \\ (C) 2007, Jody Lundrigan
}




$\begin{array}{ll}\begin{array}{l}\text { Library and } \\ \text { Archives Canada }\end{array} & \begin{array}{l}\text { Bibliothèque et } \\ \text { Archives Canada }\end{array} \\ \begin{array}{l}\text { Published Heritage } \\ \text { Branch }\end{array} & \begin{array}{l}\text { Direction du } \\ \text { Patrimoine de l'édition }\end{array} \\ \begin{array}{l}\text { 395 Wellington Street } \\ \text { Ottawa ON K1A ON4 } \\ \text { Canada }\end{array} & \begin{array}{l}\text { 395, rue Wellington } \\ \text { Ottawa ON K1A 0N4 } \\ \text { Canada }\end{array}\end{array}$

Your file Votre référence ISBN: 978-0-494-26959-6 Ourfile Notre référence ISBN: 978-0-494-26959-6

NOTICE:

The author has granted a nonexclusive license allowing Library and Archives Canada to reproduce, publish, archive, preserve, conserve, communicate to the public by telecommunication or on the Internet, loan, distribute and sell theses worldwide, for commercial or noncommercial purposes, in microform, paper, electronic and/or any other formats.

The author retains copyright ownership and moral rights in this thesis. Neither the thesis nor substantial extracts from it may be printed or otherwise reproduced without the author's permission.
AVIS:

L'auteur a accordé une licence non exclusive permettant à la Bibliothèque et Archives Canada de reproduire, publier, archiver, sauvegarder, conserver, transmettre au public par télécommunication ou par l'Internet, prêter, distribuer et vendre des thèses partout dans le monde, à des fins commerciales ou autres, sur support microforme, papier, électronique et/ou autres formats.

L'auteur conserve la propriété du droit d'auteur et des droits moraux qui protège cette thèse. $\mathrm{Ni}$ la thèse ni des extraits substantiels de celle-ci ne doivent être imprimés ou autrement reproduits sans son autorisation.
In compliance with the Canadian

Privacy Act some supporting forms may have been removed from this thesis.

While these forms may be included in the document page count, their removal does not represent any loss of content from the thesis.
Conformément à la loi canadienne sur la protection de la vie privée, quelques formulaires secondaires ont été enlevés de cette thèse.

Bien que ces formulaires aient inclus dans la pagination, il n'y aura aucun contenu manquant.

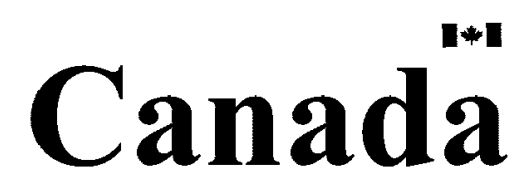




\section{Acknowledgements}

I would like to thank Thesis Supervisor, Professor Paul Davidson for his guidance and commitment to this project, even throughout his sabbatical. Without him, this thesis could not have reached completion.

I would also like to thank Advisor, Instructor Betina Kuzmarov for her comments during the proofreading process.

And finally, special thanks to my second family, a wonderful circle of friends, for their support throughout the process of becoming a Master.

- ii - 


\title{
HARD RULES OR A HANDSHAKE: \\ THE ROLE OF SOFT LAW IN RULES-BASED GOVERNANCE \\ EXAMINING THE GOVERNANCE STRUCTURE OF FINANCIAL MARKETS \\ IN EAST ASIA
}

\begin{abstract}
This thesis looks at the soft law approach for governing the finance sector in East Asia and proposes suggestions for the future governance of international economic relations. This study examines the governance structure for international economic relations, examining the role of relations- and rules-based governance in the financial markets of East Asia. It examines the inability of the current economic governance structure to adequately govern the financial sector in certain instances and appropriately react to crises in that sector. Looking at the financial crisis and the resulting legal framework for governing economic relations in East Asia, this paper examines the approach used to manage the financial sector and quell crisis, as well as the impact of that approach to governance on international economic relations.
\end{abstract}

- iii - 


\section{TABLE OF CONTENTS}

I. Introduction

II. Governance: Theoretical Development $\ldots \ldots \ldots \ldots \ldots \ldots \ldots . \ldots \ldots$

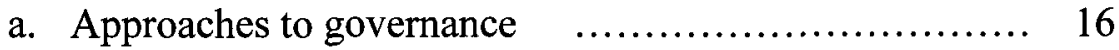

i. Relations-based governance $\ldots \ldots \ldots \ldots \ldots \ldots . \ldots 17$

ii. Rules-based governance $\quad \ldots \ldots \ldots \ldots \ldots \ldots \ldots \ldots . \ldots 18$

1. Legalization ............................ 19

2. Hard and soft law $\ldots \ldots \ldots \ldots \ldots \ldots . . . . .21$

iii. Legalization: To what degree? $\quad$............. 23

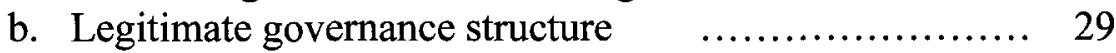

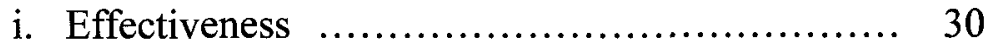

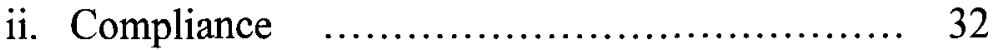

1. Comparable compliance rates............ 33

2. The role of politics $\ldots \ldots \ldots \ldots \ldots \ldots \ldots . . . \ldots 36$

iii. The legitimacy of international law f.......... 37

c. Factors impacting governance $\quad \ldots \ldots \ldots \ldots \ldots \ldots . . . \ldots 37$

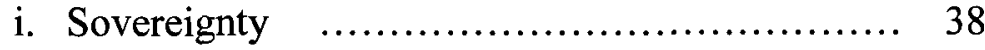

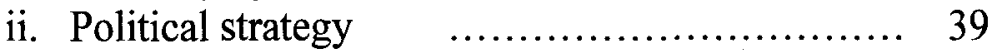

d. Governance moving forward $\ldots \ldots \ldots \ldots \ldots \ldots \ldots \ldots \ldots \ldots, 41$

III. Case Study: East Asian Financial Markets $\quad \ldots \ldots \ldots \ldots . .44$

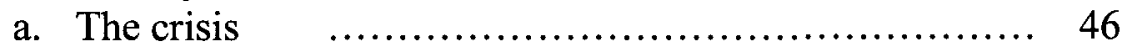

b. Responding to crisis ............................... 48

i. Asian Monetary Fund ...................... 48

ii. Manila Framework Group $\quad \ldots \ldots \ldots \ldots \ldots \ldots \ldots . \ldots$

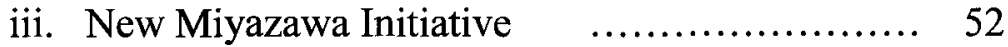

iv. Chiang Mai Initiative ......................... 54

1. The fundamentals $\ldots \ldots \ldots \ldots \ldots \ldots \ldots, 54$

2. The potential .......................... 56

c. Evolving framework $\ldots \ldots \ldots \ldots \ldots \ldots \ldots \ldots \ldots \ldots \ldots . . \ldots \ldots$

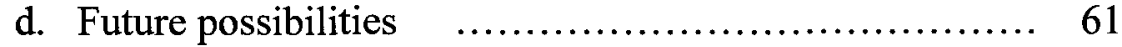

IV. Implications for Economic Governance $\ldots \ldots \ldots \ldots \ldots \ldots . \ldots 6$

a. Weaknesses in economic governance.................. 67

i. International institutions $\quad \ldots \ldots \ldots \ldots \ldots \ldots .6 \% 68$

ii. Financial markets and economic structure f.... 73

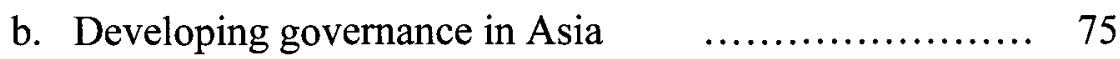

c. Political considerations $\quad$.......................... 79

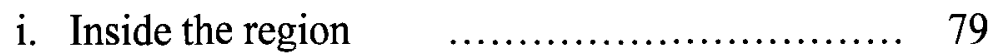

ii. Outside the region $\quad \ldots \ldots \ldots \ldots \ldots \ldots \ldots \ldots \ldots, 83$

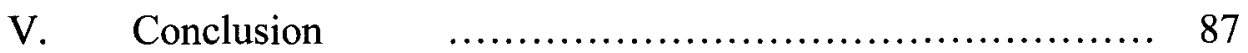

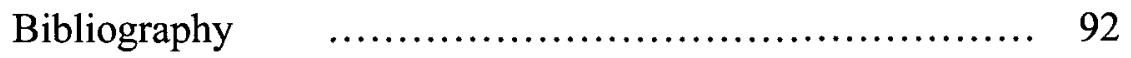

- iv - 
Chapter 1:

Introduction 
Why was the world not prepared? This is the question raised by the experiences of economic crisis after economic crisis, from Mexico to Asia to Argentina. Perhaps we fail to receive a satisfactory answer because we are asking the wrong question. A better inquiry might examine why the world was not watching. Why was the international economic governance structure not paying attention to the economies it was meant to govern? Current international economic law is based on free market ideology. Economic policies and prescriptions, associated with financial market liberalization, are being promoted by the international financial institutions as the optimal method for development and growth by economically rewarding nations for joining the global financial marketplace. However, the fact remains, that financial market liberalization was a prerequisite for the aforementioned economic crises and the governance structure allowed a butterfly flapping its wings in Thailand to lead to a hurricane that overtook the East Asian region in $1997 .^{1}$

The Asian Crisis was one of great complexity owing to the multitude of causes behind the financial disaster. The continuing debate surrounding those causes questions the wisdom in opening financial markets and hence the argument rages over the weight given to domestic structural problems versus the behaviour of international financial markets and money managers. The response of the international community to the crisis, while heavily scrutinized, has failed to produce any modification, or even evaluation, within international financial institutions or its policy prescription to liberalize financial markets. The inability of

\footnotetext{
${ }^{1}$ This metaphor is based on Chaos Theory and refers to a sensitivity to initial conditions; a phenomena where what starts as a small change can produce dramatic results over time (a butterfly flapping its wings and causing a hurricane). The "butterfly effect" is known as the Lorenz Attractor, named after an experimenter in chaos, Edward Lorenz. For information on the chaos theory see, for example, Edward Lorenz, "Deterministic Nonperiodic Flow", Journal of Atmospheric Sciences (March 1963) Vol 20, No 2; Ian Stewart, Does God Play Dice? The Mathematics of Chaos (London, England: Penguin Books, 1997). Robert Wade connects basic chaos theory to the Asian Crisis in Robert Wade, "From 'miracle' to 'cronyism': explaining the Great Asian Slump", Cambridge Journal of Economics (November 1998) Vol 22, No 6, page 700.
} 
the International Monetary Fund to properly respond to regional crises with appropriate advice has led to attempts by nations in East Asia to devise their own solutions. Crucial for success in this quest, economically and politically, is the development of an appropriate framework to provide stability and predictability in the financial markets of the East Asian region. Indeed, the Asian Crisis caught the region and the world by surprise. The region was a model for development, heralded by the international financial institutions themselves. That headline changed, almost overnight, leading to questions surrounding the ability of the current economic governance structures to avoid financial crises.

This thesis does not propose to use a specific theoretical approach; it is a policyoriented paper and thus holds no grand theoretical concepts. While a specific theoretical ideology can and will impact economic policy choices, it does not have to limit the toolbox used for solving economic problems. This paper will examine the case study of East Asia and demonstrate how alternative governance methods have developed in Asia in an attempt to provide protection from future economic problems, an area in which other systems have previously failed. It does not argue for one method over the other, it simply demonstrates how more than one approach can be useful. The inability of the current international structure to effectively govern economic relations, and the possibilities that holds for the establishment of a new or reformed legal framework, is the focal point of this thesis.

Current international economic law and its associated institutions are not always able to help countries in economic turmoil, prevent market crises or respond appropriately when problems occur as demonstrated by economic disasters in Latin America and Asia. ${ }^{2}$ Thus,

\footnotetext{
${ }^{2}$ For a full discussion of the details and similarities in the Asian and Latin American crises, see, for example, Riordan Roett and Russell Crandall, "The Global Economic Crisis, Contagion, and Institutions: New Realities in Latin America and Asia", International Political Science Review (July 1999) Vol 20, No 3; Peter Hakim, "Is Latin America Doomed to Failure?", Foreign Policy (Winter, 1999-2000) No 117; Graciela L. Kaminsky and
} 
reform of the global governance structure is needed. In response, regional initiatives are being created which offer solutions to the problems that exist within the current international structure, an example of which is one among East Asian neighbours. This initiative uses a soft law approach to governance. Soft law is an evolving, and sometimes questioned, facet of international law. ${ }^{3}$ These developing regional initiatives, which have the ability to bring economic stability and predictability to a fluctuating market economy, quell herd-like behaviour among investors, and respond appropriately when problems occur, can be seen as legitimizing soft law due to the fact that a soft law approach to governance facilitates cooperation within these initiatives. As regulation of the finance sector evolves, so too may soft law, entering the legal framework for governing international relations due to its current role in regional agreements.

The current global governance structure has been moving towards a rules-based approach to governance and the current trade regime is an example of this movement. The GATT (General Agreement on Tariffs and Trade) was a trading agreement built on the relationships between trading partners. It developed into the World Trade Organization (WTO), creating a system of rules with which to govern trade among nations. Eventually, with more nations becoming involved in the trade regime, there was a move to develop more precise rules and a more effective dispute settlement mechanism was deemed necessary. Thus, the WTO's dispute settlement body was developed with the authority to appoint panels who in turn interpret the rules and present their recommendations in order to settle disputes

Carmen M. Reinhart, "Banking Crises, Currency Crises, and Macroeconomic Uncertainty: Financial Crises in Asia and Latin America: Then and Now", The American Economic Review, Papers and Proceedings of the Hundred and Tenth Annual Meeting of the American Economic Association (May 1998) Vol 88, No 2.

${ }^{3}$ For further information on the debate surrounding soft law as its own division within international law see, for example, C. M. Chinkin, "The Challenge of Soft Law: Development and Change in International Law", The International and Comparative Law Quarterly (October 1989) Vol 38, No 4 and Harmut Hillgenberg, "A Fresh Look at Soft Law", Economic Journal of International Law (1999) Vol 10, No 3. 
among trade partners. ${ }^{4}$ Rules-based governance and the developing use of hard law govern the parties involved.

This move towards rules-based governance is thought to be the most effective method of governance as globalization brings unfamiliar partners to the negotiating table. Rulesbased governance is purporting to create a fair system for all actors, negating the possible negative implications of power politics; the rules dictate behaviour and when disputes arise there is usually a body to deal with those problems. However, the spectrum encompassed by rules-based governance (binding obligations to flexible agreements) creates a new debate. Binding obligations (hard law) are seen as legally binding signatories to their negotiated agreements, defining their behaviour and resolving problems through an obligatory dispute settlement mechanism. In contrast, the soft law typology within rules-based governance (more flexible agreements) focuses on consultation among parties and highlights the vagueness of obligations and the flexibility of implementation as factors in its success.

Under the soft law approach, there are no specific obligations, rules are open to interpretation and there is no binding dispute settlement mechanism. The question then becomes why would a party follow agreements when they are not legally obligated to do so? Global reputation as well as international and domestic political pressures factor into this

\footnotetext{
${ }^{4}$ For an explanation of the legal and institutional development in the trade sector (from the GATT to the current workings of the WTO) see, for example, Arie Reich, "From Diplomacy to Law: The Juridicization of International Trade Relations", Journal of International Law and Business (Winter 1996/Spring 1997) Vol 17, No 2/3; John H. Jackson, "Editorial Comment: The WTO Dispute Settlement Understanding Misunderstandings on the Nature of Legal Obligation", American Journal of International Law, The American Society of International Law (January, 1997) Vol 91, No 60; Patrick Moore, "Current Development: The Decisions Bridging the GATT 1947 and the WTO Agreement", American Journal of International Law, The American Society of International Law (April 1996) Vol 90, No 317. The developmental history of the WTO can also be accessed through various pages on their website. See, for example, "The WTO in Brief: Part 1. The multilateral trading system-past, present and future",

$<$ http://www.wto.org/english/thewto_e/whatis_e/inbrief_e/inbr01_e.htm $>$ [accessed on February 27, 2007].
} 
decision but most notably the flexibility of soft law brings parties to the table and facilitates the creation of a negotiated arrangement where one may not have been produced otherwise.

Compliance is cited as a major reason why soft law is not seen as a legitimate facet of international law; however, the type of agreement, hard or soft, does not seem to impact the rate of observance. ${ }^{5}$ The intended purpose of rules is to ensure fairness among all actors, to ensure all parties comply. In reality, however, rules do not always produce these results. Indeed, compliance is an issue for hard law agreements as demonstrated within the World Trade Organization; trade disputes arise, appellate body decisions made, and those rulings ignored. ${ }^{6}$ Compliance remains an issue. If compliance is an issue for hard law, then how can it be used to dismantle the argument for the inclusion of soft law as a legitimate facet of international law? If a specific party truly does not want to act in the agreed upon manner, they simply will not. The presence of binding obligations or lack thereof, has very little bearing.

Compliance is a universal issue and the evidence suggests states bestow a comparable amount of respect and recognition upon soft law agreements as they do hard law agreements. ${ }^{7}$ The rate of fulfillment does not lean heavily in the favour of either law type and it is not the purpose of this paper to produce an empirical examination of compliance rates

\footnotetext{
${ }^{5}$ Douglas M. Johnston, "Commitment and Compliance: The Role of Non-Binding Norms in the International Legal System", The American Journal of International Law (2001) Vol 95, No 3, page 710.

${ }^{6}$ The problems of compliance experienced in association with the hard law agreements of the WTO are exemplified in the Softwood Lumber Dispute, in which the United States violated international economic law and after two panel rulings cited this breach, they still refused to comply or pay full retribution. This case will be discussed in Chapter 2 under the section titled, "Comparable compliance rates." For further information see, for example, "Indepth: Softwood Lumber Dispute" (dated August 23, 2006) $<$ http://www.cbc.ca/news/background/softwood_lumber/> [accessed on November 16, 2006]; "Softwood Lumber", Export and Import Controls, Foreign Affairs and International Trade Canada (last updated October $11,2006)<\mathrm{http}: / / \mathrm{www}$.international.gc.ca/eicb/softwood/intro-en.asp> [accessed on November 16, 2006]; "Dispute Settlement", Foreign Affairs and International Trade Canada (last updated November 11, 2006) $<$ http://www.dfait.maeci.gc.ca/tna-nac/dispute-en.asp> [accessed on November 16, 2006].

${ }^{7}$ Anthony D'Amato and Kristin Engel, International Environmental Law Anthology (Ohio: Anderson Publishing Company, 2001) <http://anthonydamato.law.northwestern.edu/IELA/Intech05-2001-edited.pdf $>$ [accessed on November 3, 2006], page 56.
} 
between the two. The point being made in this paper is, if we have two comparable governance options which have both proven their ability to produce agreements and then produce compliance with those agreements, there is no logical reason not to grant both choices legitimacy and expand the legally accepted options available to parties attempting to create international arrangements. With a proven track record, the only explanation for the exclusion of soft law from the purview of international law must then be political, politics being, arguably, the most influential factor upon legal frameworks and the subsequent governance structure.

International politics is an incredibly complex weave. While domestic interests first and foremost govern choices in international relations, with globalization there is now an international element to a state's interests; a state's status and reputation on the global stage is a huge concern. The battle for status in the international economy brings successful competitors power to influence the economic system. Thus, in a globalized world it is not good enough to be doing well (have a healthy economy, low unemployment rate, high GDP whatever your measurements), a state must be doing well in comparison to all other nations. It is a competition that is rampant and individualistic. And this competition is most especially exemplified in the political strategies of the Western hemisphere. These Western states have been the successful competitors, if you will, thus far and it is not coincidental that they were also the creators of the current international legal framework and the subsequent global governance structure in which they are enjoying great economic, political and social success. The current international legal framework has not serviced "the rest" of the world in the same fashion. This has led state leaders in other parts of the world to search out and implement alternative strategies. These leaders are skeptical about using legalized forms of agreement 
which maintain the status quo and they have found alternative strategies for cooperation that should not and cannot be negated by rhetoric based on double-standards and political strategizing.

The global financial architecture has been built on the basis of free market economic and political philosophies to the exclusion of alternative policies. The legal framework developed from this ideology has made a "move to rules," as international financial institutions are first created and then they create legal agreements, outline obligations and empower dispute settlement mechanisms. After examining the interconnected terms of governance, legalization and the subsequent approaches to governance, Chapter 2 will discuss to what extent the international community has actually made this "move to rules."

Supporters of hard law, rules-based governance believe that without such legal obligations, there would be no incentive to comply with agreements. However, these highly legalized relations can intimidate some stakeholders and do not create a suitable environment in which to pursue cooperation in many sectors. The legitimacy of soft law will then be examined as Chapter 2 looks at the effectiveness of soft law agreements.

The debate surrounding the necessity for legal obligations and hard law abound due to the above mentioned issue of compliance. Chapter 2 examines the idea of compliance and its implications for both soft and hard law, outlining how the two produce comparable compliance rates.

With the impossibility, or at least extreme difficulty, of separating law and politics, the chapter will close with a discussion of some political factors, which impact governance and the policy choices made by states in terms of their approaches to governance. 
The purpose of this paper is to judge the desirability of opening up the current governance structure to alternative methods for cooperation. Using East Asia as a case study, this paper examines how a softer approach to agreement-making may carry influence beyond that of hard legislation. In Asia, there is a preference for soft law and without it agreements would be difficult to produce. In Chapter 3, the legal framework for governing East Asia's finance sector, which developed from the Asian Crisis, will be outlined.

The free hand of the market did not move to correct problematic indicators in certain economies in East Asia, although these issues were quite evident. Participants in the financial system, the international financial institutions in particular, were unable to avoid the crisis. Indeed they were as shocked as the rest of the world when the crisis hit. It would seem logical that should the current legal framework for regulating economic activity be unable to protect domestic and regional economies from financial crises, that reform of that structure using some alternative approach is necessary.

The development of regional initiatives in East Asia, as a result of the Asian Crisis and the inappropriate response of the international community, present an opportunity for reform. It also provides an alternative framework for protecting economies from future financial disaster. Since 1997, regionalism in East Asia has grown and so has the willingness and determination of states within the region to cooperate on financial issues. They are forming a regional partnership in order to better protect themselves from the volatile nature of financial markets, and the region from another financial crisis. Chapter 4 examines this development and the implications it carries for soft law and its place within economic governance. 
Members of the Association of Southeast Asian Nations (ASEAN) in cooperation with Japan, China and Korea have established the ASEAN +3 coalition of countries and have produced the Chiang Mai Initiative (CMI). The Chiang Mai Initiative was adopted in 2000 at the meeting of the ASEAN + 3 finance ministers in order to strengthen policy dialogue and regional cooperation, provide support for nations experiencing liquidity problems and, ultimately prevent the occurrence of another financial crisis. ${ }^{8}$ The creation of the Chiang Mai Initiative in East Asia is a response to a failing international system and a request for support from those who understand the environment in which East Asian economies must pursue economic growth. The possibilities for the evolution of the Chiang Mai Initiative are enormous and include institutionalization. Although the agreement developed on a relationsbased governance approach, it has evolved into a rules-based governance structure, albeit a soft one, and future possibilities are not limited to that approach. With its use of soft law in governing East Asia's finance sector, the Chiang Mai Initiative can and should be seen as a developing legal framework for regulating economic activity and as a means for reforming the global financial architecture.

In Chapter 5, the paper outlines the implications for economic governance that can result from the use of a soft law approach to governance in regulating regional financial agreements. It hypothesizes that the international legal framework and the subsequent economic governance structure will include soft law as regulation of the finance sector evolves and draws lessons from the experiences in East Asia. Expanding the definition of

\footnotetext{
8 "Regional Financial Cooperation in East Asia: The Chiang Mai Initiative and Beyond", Bulletin on AsiaPacific Perspectives <http://www.unescap.org/pdd/publications/bulletin2002/ch8.pdf $>$ [accessed on March 2, 2005], page 90 .
} 
international law and encompassing all legitimate forms of governance can only aid in legitimizing international law itself.

It is important to realize that calls for reforming any institution, framework or system, stem from some failure of the current structure. Presenting an alternative legal framework that appropriately deals with the problems of the current system is the responsibility of the international community. As opposed to sitting in the corners of our respective ideological camps, the opportunity presents itself for the development of a framework in which economic stability can be realized. Facilitating cooperation among historical rivals in East Asia demonstrates that there is a significant role for soft law to play in the governance of financial markets. Taking the lead from those rivals, the tents at either end of the governance camp should pull up their pegs and engage in a dialogue which supports whichever type of agreement compliments the circumstances at hand.

There are instances where following the rules and procedures of the governance structure do not produce desirable results. In fact, in times of crisis - as experienced by East Asia during the Asian Crisis of $1997 / 98$ - the rules have failed in their mandate to regulate financial markets, protect economies from economic decline and rebuild the damage caused by financial crisis. Thus, if general agreement can produce beneficial results without the presence of hard law rules-based governance, then the toolbox used for dealing with financial crisis and, by extension facilitating economic cooperation, may have a whole new set of tools.

It is possible, and logically quite beneficial, to have multiple policy options. No two states have the exact same economic circumstances and different circumstances require different solutions. 
This paper does not argue for one particular policy option, it simply demonstrates how alternative policies are producing successful international agreements and thus should be granted legitimacy. In an international environment where economies are failing and producing dire economic, political and social situations for global citizens, if alternative methodologies for international cooperation can help to alleviate such circumstances, they should be granted legitimacy and recognized as a workable facet of the economic governance structure. Currently soft law is not formally accepted as international law and its heavily debated exclusion is the focus of this paper as it is facilitating cooperation in East Asia's finance sector.

It serves the international community as a whole to have successful economies and currently there is major debate surrounding the ability of the current international structure to achieve that end, to effectively govern economic relations and produce positive economic, political and social circumstances for individuals, groups, states and regions. This debate, itself, implies the need for reform of the current governance structure through the inclusion of sound alternative policy options and perhaps even the establishment of a new legal framework if the current structure is neither reforming nor effectively governing economies in crisis. 


\section{Chapter 2:}

Governance: Theoretical Development 
Governance is a term without a universal definition, yet one which has come to be an overarching and indeed tremendously important term for defining international relations. When narrowed to the concept of global governance, the definition must account for all factors impacting state relations. These factors - frameworks and institutions - are intertwined and inseparable in many instances and create a complex international relations system, which attempts to explain the behaviour and actions of states. As the lens is focused, typologies of governance emerge from the mass of factors intertwining to create the system in which economic relations are governed. This chapter will begin by exploring these typologies to define and determine the role of rules- and relations-based governance models.

There appears to be a general consensus among governance scholars that international relations is moving towards a rules-based approach to governance. ${ }^{9}$ Despite the appearance that rules are becoming the dominant model of governance, the appropriate level of legalization encompassed within these rules is still heavily debated. Attempting to define legalization, the chapter will examine the concept along a spectrum running from hard rules to soft law, and discuss the role each plays in the governance of economic relations.

With all levels of legalization being used within the wide array of international economic relationships, the role of soft law and its place within a rules-based economic governance structure will be discussed. Seen by some scholars and economists as lacking strong commitment, the placement of soft law within the governance structure is scrutinized, and is even seen by some as corrosive to the power and legitimacy of law. ${ }^{10}$ Soft law is often

\footnotetext{
${ }^{9}$ For further information on international relations' move towards rules see, for example, Avinash Dixit, "Lawlessness and Economics: Alternative Modes of Economic Governance", Gorman Lectures - University College, London (December 2002) <http://www.econ.ucl.ac.uk/downloads/Lecl.pdf > [accessed 29 November, 2005] and Judith L.Goldstein, Miles Kahler, Robert O. Keohane, Anne-Marie Slaughter, "Introduction: Legalizations and World Politics", in Judith L. Goldstein, Miles Kahler, Robert O. Keohane, Anne-Marie Slaughter, eds. Legalization and World Politics (Cambridge: MIT Press, May 2001).

${ }^{10}$ Anthony D'Amato and Kristin Engel, supra note 7, page 3-5.
} 
used in international arrangements due to the ease in finding common ground among differing parties and thus is seen by some scholars as a precursor to hard legalized agreements. ${ }^{11}$ However, with the widespread use of soft law, it has its own place in the governance of international relations and should be seen as its own facet within the evolving rules-based governance structure.

Whatever the role of soft law, its very use lends evidence to the argument that the rule-oriented movement of the international community is not based wholly on binding obligations. The extent to which international relations is rules-based will impact how states interact, politically and economically, terms, which are difficult if not impossible to separate. Examining international financial institutions, the apparent choice of the international community to favour heavily legalized rules-based governance is not as clear-cut as it would appear.

While global relations is hypothesized as moving towards rules-based governance, some of these rules are quite soft, lacking binding commitments on the part of their signatories. The lack of binding obligations has been purported as a recipe for noncompliance, however, soft law agreements show comparable compliance rates with those based on hard law. ${ }^{12}$ This highlights the debate surrounding compliance and enforcement issues, which are consistently cited as obstacles for the legitimization of soft law. The compliance rates of both hard and soft law will be discussed along with the legitimacy of the compliance argument against soft law.

The chapter will close with a dialogue surrounding the issue of sovereignty and the strategic choices impacting the selection of governance approaches. Politics and law are not

\footnotetext{
${ }^{11}$ Joseph Gold, "Strengthening the Soft International Law of Exchange Agreements", The American Journal of International Law (1983) Vol 77, No 3, page 444.

${ }^{12}$ Douglas M. Johnston, supra note 5.
} 
easily separated, if indeed they can be at all. The influence of politics upon governance approaches is significant, often times dictating policy choices. The use of a less formal agreement can quell some issues of concern but in the end, it is political strategy that dictates which type of agreement a party signs.

The very fact that soft law is used by parties to reach agreement illustrates a need which has not been, or perhaps cannot be, met within a rules-based governance structure of international economic relations containing a high level of legalization. Soft law can have a place in bridging this gap and thus have a prominent role in the rules-based governance structure of economic relations.

\section{APPROACHES TO GOVERNANCE}

Good governance is essential to the development of socially responsible and mutually beneficial relations among states. Governance refers to the multitude of methods used by public and private institutions to manage their affairs; the approach by which they regulate their affairs (formally within institutions or informally through general agreements) and resolve disputes among stakeholders. ${ }^{13}$ In this paper, the definition of governance on a global level will be discussed as we take into account all factors in the international community that influence state decision-making.

Global governance ... refers to the complex of institutions, mechanisms, relationships, and processes between and among states, markets, citizens, and

\footnotetext{
${ }^{13}$ As previously stated, governance is a term without a universal definition. The description used here is meant to encompass the various factors associated with the idea of "governance." For additional definitions and explanations regarding the term governance see, for example: Commission on Global Governance, Our Global Neighbourhood (New York: Oxford University Press, 1995); David Kennedy, "New Approaches to Comparative Law: Comparativism and International Governance", Utah Law Review (1997) No 545; Tim Plumptre, "What is Governance?", Institute on Governance <http://www.iog.ca/page.asp?pageID=3\&HTMLAREA=HOME > [accessed on February 28, 2007].
} 
organizations to articulate collective interests on the global plane, establish rights and obligations, and mediate differences. ${ }^{14}$

It takes into account all possible factors influencing decision-making in state relations and typically refers to the use of regulation in governing these affairs. ${ }^{15}$

\section{RELATIONS-BASED GOVERNANCE}

When discussing state and international stakeholder interaction, two approaches are cited as possible methods of governance, rules-based and relations-based governance. Relations-based governance relies on the relationships of the stakeholders to dictate their behaviour and create mutual agreement. ${ }^{16}$ The desire to maintain a good relationship is the driving force behind cooperation among the actors and is relied upon to ensure compliance; the maintenance of these relations is the enforcement mechanism. ${ }^{17}$ The mutual knowledge and understanding of stakeholders is the key element in coming to agreement without the presence of obligations. Relations-based governance focuses on,

...informality rather than a legalistic framework, adopting the principles of accommodation and consensus in decision making and non-interference in the domestic affairs of its members, and accommodating the needs of members at different levels of economic development. ${ }^{18}$

\footnotetext{
${ }^{14}$ Richard Jolly, Louis Emmerji and Thomas G Weiss, The Power of UN Ideas: Lessons from the First 60 years (New York: United Nations Intellectual History Project Series, May 2005)

$<$ http://www.unhistory.org/UNIdeas.pdf $>$ [accessed on February 20, 2007], page 47.

${ }^{15}$ Elke Krahmann, "National Regional, and Global Governance: One Phenomenon or Many?", Global Governance (2003) Vol 9, page 323.

${ }^{16}$ John Shuhe Li, "Relations-based versus Rule-based Governance: an Explanation of the East Asian Miracle and Asian Crisis", Review of International Economics (2003) Vol 11, Issue 4, page 656.

${ }^{17}$ Ibid.

${ }^{18}$ Miles Kahler, "Legalization as Strategy - The Asia-Pacific Case", International Organization. (2000) Vol 54, No 3, page 552.
} 
Two principles, lying at the core of this ideology, which are used in the Association of Southeast Asian Nations' (ASEAN) standard operating procedures for governing relations among partners in Southeast Asia, are expressed in the Malay terms: musyawarah (consultation) and mufakat (consensus). Miles Kahler explains,

The first [musyawarah] defines a process of decision making that involves painstaking and lengthy discussion and consultation in which decisions emerge from the bottom up. That process aims to achieve eventual consensus [mufakat] —unanimity or near-unanimity—as a much-valued result. ${ }^{19}$

Due to the historical and cultural relevance of these terms, relations-based governance is often referred to as the "Asian way" of negotiation. The concepts of consultation and consensus continue to influence Asian economic relations but the use of relations-based governance has decreased significantly as the world becomes more globalized and strangers enter into negotiated agreements with each other. The Asian way carries its influence into a more rules-based approach to governance as Asian nations themselves move towards a more obligatory approach. ${ }^{20}$

\section{RULES-BASED GOVERNANCE}

Rules-based governance is a more formal governance methodology. With the development of rules, there is less need to know and understand your partners as the rules dictate their behaviour and action (arguably negating the role of power politics as the rules,

\footnotetext{
19 Ibid.

${ }^{20}$ Peter Hendy, "Engaging Asia", Australian Chamber of Commerce and Industry, Faculty of Asian Studies Australian National University (August 15, 2004) $<$ http://www.acci.asn.au/text_files/speeches_transcripts/2004/Engaging\%20Asia\%20Speech\%20$15 \% 20$ August\%202004.pdf $>$ [accessed on February 28, 2007], page 18.
} 
not political will, dictate behaviour). ${ }^{21}$ However, rules-based governance encompasses a wide spectrum of policy choices when it comes to reaching agreements, along which obligatory behaviour and the role of power politics vary immensely. The level of legalization within particular arrangements dictates the "hardness" or "softness" of the rules-based governance structure (discussed fully below). On one end of the spectrum, "hard law" uses negotiated binding obligations, dispute settlement mechanisms to enforce these obligations and often, if not always, creates institutional structures to facilitate cooperation. "Soft law," on the other hand, does not require legally binding rules, has flexible implementation plans and relies on consultation among parties to resolve disputes. These two ends of the spectrum as well as the multitude of options in between, which act to facilitate international cooperation, are all encompassed within the rules-based governance approach. ${ }^{22}$

\section{Legalization}

As relations-based governance becomes a rarity and parties turn to rules for predictability and stability in agreement-making, the depth of rules replaces the question of whether to use rules at all. The rules-based approach to governance carries varying degrees of legalization, which according to Abbott et al, contains three essential characteristics.

"Legalization" refers to a particular set of characteristics that institutions may (or may not) possess. These characteristics are defined along three dimensions: obligation, precision, and delegation. Obligation means that states or other actors are bound by a rule or commitment or by a set of rules or commitments. Specifically, it means that they are legally bound by a rule or

\footnotetext{
${ }^{21}$ John Shuhe Li, supra note 16, page 651-673.

${ }^{22}$ The spectrum (referred to here) which encompasses the various levels of legalization within the rules-based approach to governance was taken from "The dimensions of legalization" in Kenneth W. Abbott, Robert O. Keohane, Andrew Moravcsik, Anne-Marie Slaughter, and Duncan Snidal, "The Concept of Legalization", in Judith L. Goldstein, Miles Kahler, Robert O. Keohane, Anne-Marie Slaughter, eds. Legalization and World Politics (Cambridge: MIT Press, May 2001), page 20.
} 
commitment in the sense that their behavior thereunder is subject to scrutiny under the general rules, procedures, and discourse of international law, and often of domestic law as well. Precision means that rules unambiguously define the conduct they require, authorize, or proscribe. Delegation means that third parties have been granted authority to implement, interpret, and apply the rules; to resolve disputes; and (possibly) to make further rules. Each of these dimensions is a matter of degree and gradation, not a rigid dichotomy, and each can vary independently. ${ }^{23}$

The level of legalization involved in the rules-based approach dictates the "hardness" or "softness" of the obligations along a scale from legalized obligatory rules to complete absence of legalization, which is illustrated in Figure 1 (below).

The level of legalization is illustrated by the placement of an agreement along the spectrum of each and all three characteristics (identified above). When an agreement contains high obligation, precision and delegation, then it is considered a hard law agreement whereas an agreement showing lower strength in these characteristics will be seen as a softer form of law. This continues until there is almost complete absence of legalization and thus very little, if any, indication of obligation, precision or delegation present in the agreement.

Obligation

Expressly Binding rule

nonlegal norm<------------------------>(jus cogens)

Precision

Vague Precise, highly

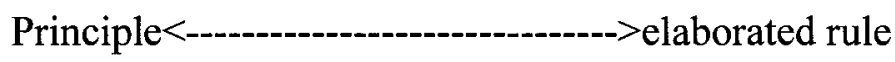

${ }^{23}$ Kenneth W. Abbott, Robert O. Keohane, Andrew Moravcsik, Anne-Marie Slaughter, and Duncan Snidal, "The Concept of Legalization", in Judith L. Goldstein, Miles Kahler, Robert O. Keohane, Anne-Marie Slaughter, eds. Legalization and World Politics (Cambridge: MIT Press, May 2001), page 17. 


\section{Delegation}

Diplomacy<----------------------------->International court, organization;

domestic application

Figure 1. The Dimensions of legalization

(Source: Abbott, Kenneth W., et al, 'The Concept of Legalization', (2000) 54 (3) Intl Organization)

\section{Hard law and soft law}

"The Dimensions of legalization" (Figure 1) illustrates the characteristics of soft and hard law according to their placement on the spectrum of legalization. An arrangement can be considered a "harder" form of law the more prevalent the characteristics of obligation, precision and delegation and "softer" when these characteristics are not as pervasive. Hence placing the terms along a variable spectrum aids in explaining concepts, which lack a concrete definition.

Hard law tends to possess more tangible and measurable elements due to its overall formality and detail. Having said that, the terms "hard law" and "soft law" are difficult to separate and are often defined through a comparison of one another. David Trubek, Patrick Cottrell and Mark Nance, define hard law as having "features such as obligation, uniformity, justiciability, sanctions, and/or an enforcement staff..." and anything not possessing these qualities is "classified as 'soft law.",24

\footnotetext{
${ }^{24}$ David Trubek, Patrick Cottrell and Mark Nance, "'Soft law,' 'Hard law,' and European Integration: Toward a Theory of Hybridity", NewGov: New Modes of Governance (dated February 2006) <http://www.eu-
} 
While a specific definition of soft law is not prevalent, "the distinctive characteristic of soft law appears to be the intended vagueness of the obligations that it imposes or the weakness of its commands." 25 Soft law does not tend to carry high levels of obligation, precision and delegation; it does not legally bind signatories to specific rules nor do these rules define the action or behaviour of the parties in question. In addition, there is rarely a third party to which disputes are delegated for resolution. Softer law depends on conciliatory agreement, leaves the process of implementation in the hands of the signatories and relies on parties to resolve disputes through consultation. There are varying degrees of soft law where the characteristics of obligation, precision and delegation differ from one agreement to the next, but they separate themselves from hard law by using language such as "guidelines" or "declarations" or "principles." 26 In order to be considered a valid form of international law, however, they must be complied with despite the language used. According to Joseph Gold, "The essential ingredient of soft law is an expectation that the states accepting these instruments will take their content seriously and give them some measure of respect." ${ }^{27}$ The ability of soft law agreements to meet these expectations is the ultimate test of their legitimacy.

The extent to which levels of legalization determine success with international agreements is highly debatable but agreements without highly developed rules have been signed and continue to report high compliance rates. ${ }^{28}$ Critics of hard law point out several factors, which may limit its usage in certain circumstances. Trubek, Cottrell and Nance note,

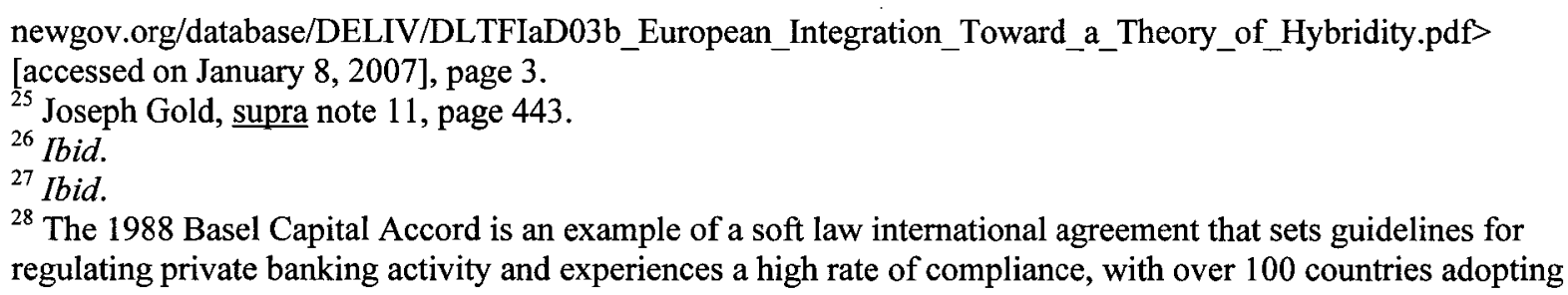


-Hard law tends towards uniformity of treatment while many current issues demand tolerance for significant diversity among Member States.

-Hard law presupposes a fixed condition based on prior knowledge while situations of uncertainty may demand constant experimentation and adjustment.

-Hard law is very difficult to change yet in many cases frequent change of norms may be essential to achieve optimal results.

-If actors do not internalize the norms of hard law, enforcement may be difficult; if they do, it may be unnecessary. ${ }^{29}$

It is futile to position the debate surrounding the preference for hard or soft law in a philosophical position; it needs to focus on the functioning of each in practical

circumstances. The tendency to pitch these terms against each other is a counter-productive method of evaluation as both types of law are used in international relations and have produced success. Increasingly, both hard and soft law are combined within a single agreement. The benefits of each law type will vary depending on the agreement itself, the parties involved and the goal of the signatories. Indeed, hard and soft law each carries costs and benefits.

\section{LEGALIZATION: TO WHAT DEGREE?}

A rules-based approach does not necessarily have to encompass specific obligations, which incur consequences if those obligations are not met. Other methods for agreement are available and even more desirable in some circumstances. Close examination of institutions

\footnotetext{
the recommendations. The following sources can be referenced for further information: Caroline Gavin and Rebecca Stuart, "Regulatory Developments in the Capitalisation of Banks - A Financial Stability Prespective", Financial Stability Report (2005); Michael R. King and Timothy J. Sinclair, "Private Actors and Public Policy: A Requiem for the New Basel Captial Accord", International Political Science Review (2003) Vol 24, No 3; "Basel Committee on Banking Supervision", Risk Glossary

$<$ http://www.riskglossary.com/articles/basle_committee.htm> [accessed on November 15, 2006];

"Memorandum for Chief Executive Officiers", The Office of Thrift Supervision, Department of Treasury (1989) <http://www.ots.treas.gov/docs/2/25135.pdf> [accessed on November 15, 2006].

${ }^{29}$ David Trubek et al, supra note 24 , page 4 .
} 
like the WTO reveal an initial conciliatory approach to dispute settlement. In regards to international financial markets, the International Monetary Fund (IMF) - the international institution with a mandate of managing financial exchange among nations - does not technically have a mechanism to impose obligations or penalize states for failure to follow the monetary policy of international financial institutions, only the soft power of persuasion. ${ }^{30}$ This brings into question the degree to which the governance structure is rulesbased and whether the governing of international economic relationships needs to be heavily legalized.

International institutions, even heavily legalized ones, often have a conciliatory approach to reaching agreements. The World Trade Organization is an example of a heavily legalized rules-based governance structure. It facilitates legally binding trade agreements and, as an institution, has high levels of obligation, precision and delegation. Signatories to its agreements are bound by their commitments, their conduct in relation to these commitments is well-defined and should a problem arise, there is a third party mechanism in place to resolve disputes, the dispute settlement body. Despite such a high level of legalization, the institution continues to support a conciliatory approach to dispute settlement. ${ }^{31}$

The WTO is a hard law, rules-based organization, however, it is not purely legalistic. Even with a high level of legalization as the backbone to the organization, prior to bringing disagreements to the dispute settlement body, the WTO mandates parties attempt to negotiate

\footnotetext{
${ }^{30}$ Edwin M. Truman, "Introduction and Summary", in Edwin M. Truman, eds. Reforming the IMF for the $21^{\text {st }}$ Century, Institute for International Economics, Special Report 19 (April 2006)

$<\mathrm{http} / /$ www.iie.com/publications/chapters_preview/3870/01iie3870.pdf $>$ [accessed on February 28, 2007], page 3.

${ }^{31}$ Shin-yi Peng, "The WTO Legalistic Approach and East Asia: From the Legal Culture Perspective", AsianPacific Law and Policy Journal (2000) Vol 1, Issue 2, page 24.
} 
a solution to the problem. Shin-yi Peng explains this deviation from an approach to governance based on hard legalization.

A closer examination of the new DSU [Dispute Settlement Understanding] reveals that the DSU's dispute resolution methods are not 'purely' legalistic. The DSU makes available both power-oriented as well as rule-oriented approaches for dispute settlement under the WTO. Most significantly, 'consultation remain[s] a mandatory first step in the dispute settlement process,' and good offices, conciliation, and mediation remain as options. Indeed, the WTO dispute settlement method does not always involve a confrontational approach, and the mandatory consultation stage is designed to preempt difficult negotiations between parties. ${ }^{32}$

As of July 2005, 332 disputes were brought to the WTO, and a significant number of them (202) were resolved out of court. ${ }^{33}$

The WTO, an international institution governing global economic relations, not only allows for, but mandates, deviation from a purely legalistic approach. It realizes the intrinsic value (and resource-saving ability) of consultation, diplomacy and power relations in reaching agreement and aiding in the settlement of disputes. This indicates the importance of negotiation and a flexible method for reaching agreement, which is outside the boundaries of a hard law approach to economic governance. Although consultations take place within the context of the rules, the fact that consultation is promoted gives legitimacy to a less legalistic path to reaching an arrangement and illustrates that the international structure governing economic relations recognizes the necessity for using a "softer" approach to dispute settlement.

The WTO may not be a purely legalized institution but it has moved considerably in that direction from its origin as the General Agreement on Tariffs and Trade (GATT). The

${ }^{32}$ Ibid.

33 "Understanding the WTO: Settling Disputes. A unique contribution", World Trade Organization $<$ http://www.wto.org/english/thewto_e/whatis_e/tif_e/disp1_e.htm> [accessed on February 9, 2007]. 
GATT system that developed was based on diplomacy and became more "judicial" over time, leading to the creation of the WTO. However, the fact that other international economic institutions, such as the International Monetary Fund (IMF), have not made this same shift indicates that not all sectors are best governed by a more legalized rules-based approach to governance.

The IMF is the international institution governing economic relations in the finance sector. It has formalized Articles of Agreement, which each member of the organization must sign and adhere to in order to acquire membership. The Articles of Agreement, as is evident from the title, are not legal requirements and in no way hold binding obligations upon the organization's membership. Indeed, the IMF exist primarily to "provide advice" to member countries and provide them with a forum to discuss financial issues. ${ }^{34}$ The use of soft law as the central instrument of the institution reflects the diversity of its membership, which ranges from states at the very lowest level of development to highly developed first world nations. When the IMF enters into agreements with individual nations (to solve balance of payments problems, etc), the state in question signs an agreement which outlines the dispersion of funds and policy advice from IMF officials and field officers, which are in turn supposed to be implemented by the state. Technically, the IMF cannot retaliate against nations that do not follow their policy prescriptions and do not use funding in ways recommended by the Fund. There is no enforcement mechanism, but members agree to subject their economic and financial policies to the scrutiny of the international community as well as make a commitment to pursue policies that are conducive to the IMF's goals and objectives. ${ }^{35}$ In this way, the IMF can be considered an institution using a soft law approach to governance

\footnotetext{
34 "What is the IMF?", International Monetary Fund (dated September 30, 2006)

$<$ http://www.imf.org/external/pubs/ft/exrp/what.htm> [accessed on February 28, 2007].

${ }^{35} \mathrm{Ibid}$.
} 
(although there is a level of legalization present) and there are no plans to reform the structure of the institution to create a more hard law membership agreement. The overarching soft law governance structure of the 'Articles' remain the main component of the IMF and lend legitimacy to the approach in governing the finance sector and international agreements in general.

The main legal instrument to be examined is the Articles of Agreement of the International Monetary Fund. It is not the only legal instrument of the system, but the functions of the Fund, the size of its membership, and the volume of its financial resources justify recognition of the Articles as the central instruments of the system.

This international legal framework for governing the finance sector relies heavily on a soft law approach showing that while there is a general "move to rules," there is room within the structure for soft law approaches where appropriate. These "rules" do not necessarily have to be completely dictated by legally binding obligations; there are softer - and equally effective - methods of governance that can be used on their own or as a supplement to hard law.

There is no mechanism in the IMF to ensure compliance and there is no third party dispute settlement mechanism. As an institution, it has a low level of legalization but the IMF is still seen as a legitimate institution in international economic governance. Its apparent satisfaction with its current level of legalization highlights the lack of movement towards a structure with a more legally binding rules-based approach to governance and its inclusion in the economic governance structure helps to legitimize soft law. If the IMF's Articles of Agreement are seen as legal instruments then surely other soft law agreements should be given the same respect and granted legitimacy under international law.

${ }^{36}$ Joseph Gold, supra note 11 . 
Internationally, a move towards rules-based governance has been observed. ${ }^{37}$ The influence of powerful states and other stakeholders in international relations which have historically used a more rules-based approach to governance have moved the climate and method of regulating global relationships in that direction. The Western world has a tendency to rely on institutions and structures to define relations and establish rules for behaviour among parties. ${ }^{38}$ This emphasis on using legal frameworks and institutions to reach agreement and dictate relations is considered a hard law rules-based approach to governance. This method is seen by legalists as the most appropriate way to predict the behaviour and actions of parties when entering into an agreement with unfamiliar partners. Establishing rules is seen to dictate the behaviour and actions of signatories and create a more predictable relationship.

Historically, Southeast Asia has preferred a relations-based approach to governance focusing on informality and consensus decision-making. ${ }^{39}$ In addition, accommodations for state sovereignty and various levels of individual state economic development in the region have always been of great concern. ${ }^{40}$ As Asia opened itself up to global influences through

\footnotetext{
${ }^{37}$ See references in footnote 9 , above.

${ }^{38}$ The tendency of Western Europe and North America to favour formal legalized institutions and structures is noted in Miles Kahler, "Legalization as Strategy - The Asia-Pacific Case", International Organization (2000) Vol 54, Issue 3. Explanations for this preference are offered in Kenneth W. Abbott and Duncan Snidal, "Hard and Soft Law in International Governance", International Organization (2000) Vol 54, Issue 3 as well as in José Antonio Ocampo, "The Role of Regional Institutions" in Jan Joost Teunissen, eds. A Regional Approach to Financial Crisis Prevention: Lessons from Europe and Initiatives in Asia, Latin America and Africa (The Hague: FONDAD, November 2002) <http://www.fondad.org/publications/regional/Fondad-RegionalApproach-BookComplete.pdf $>$ [accessed on February 20, 2007] who respectively point out that powerful states influence rules and associated institutions and that world institutions serve states with power and influence.

${ }^{39}$ Asia's preference for a relations-based approach to governance was discussed in the "Relations-based governance" section of this chapter. The following sources can also be referenced for information regarding Asia's historic preference for less legalized institutions: Miles Kahler, "Legalization as Strategy - The AsiaPacific Case", International Organization (2000) Vol 54, Issue 3 and Judith L.Goldstein, Miles Kahler, Robert O. Keohane, Anne-Marie Slaughter, "Introduction: Legalizations and World Politics", in Judith L. Goldstein, Miles Kahler, Robert O. Keohane, Anne-Marie Slaughter, eds. Legalization and World Politics (Cambridge: MIT Press, May 2001).

${ }^{40}$ Joseph Gold, supra note 11.
} 
political discourse, trade talks and financial market liberalization, it found unfamiliar partners sitting down to the table to discuss such issues. As a result, a more rules-based approach was adopted by Asian negotiators to create predictability when discussing and agreeing to economic partnerships. While noting the influence of international financial institutions and powerful Western states to move the international community towards a rules-based approach to governance, a more economically influential Asia may influence the way rules are defined under international law in the future.

While Asia appears to be moving towards rules, these rules are not heavily legalized. This causes debate surrounding their legitimacy and place as part of international law and the governance structure of international relations. Asia's rising economic power and relationsbased history may have major implications for an international legal system previously dominated by economic power houses in the West which have been predisposed to the status quo definitions of law and governance.

\section{LEGITIMATE GOVERNANCE STRUCTURE}

Soft law has long been a major part of international law and the governance structure of international relations, even if not officially (the GATT being one example). ${ }^{41}$ The line between law and non-law, legally binding and non-binding is not clear cut and is, politically, nearly impossible to distinguish. Although soft law brings its own benefits such as making it easier to reach agreements, safeguarding sovereignty, and lowering transaction costs, some legalists are beginning to accept its use based on the belief it eventually leads to more legalized arrangements and if nothing else provides guidelines for state action where there

\footnotetext{
${ }^{41}$ Harmut Hillgenberg, "A Fresh Look at Soft Law", Economic Journal of International Law (1999) Vol 10, No 3, page 499 .
} 
would otherwise be anarchy. ${ }^{42}$ This is not the sole use of soft law. Soft law can work in several capacities to promote agreement-making, which can include acting as a bridge between soft and hard law, as a precursor to hard law or as its own legitimate facet of international law. In either capacity - and due to its multiple possibilities for developing legal arrangements - soft law has a legitimately significant role to play in international relations.

\section{EFFECTIVENESS}

Including non-binding agreements as a legitimate facet of the rules-based governance approach can fill the gaps left exposed by hard law. There are many reasons why states may not sign hard law agreements. One of those reasons is the difficulty in renegotiating elements of an agreement, which no longer benefit or coincide with domestic circumstances. Mariely Lopez-Santana explains, "once a set of proposals become binding law the opportunities for changing or adapting these legislations are limited." ${ }^{\prime 33}$ Thus, the static nature of hard law can cause no arrangement to be made at all, or lead states toward soft law agreements. Indeed, the legal obligations of hard law can cause states to opt out of negotiations altogether.

States realize from the outset of negotiation that easy solutions do not exist and that too rigidly-defined obligations would only lead to inefficiency by deterring a significant number of concerned governments from ratifying the convention. ${ }^{44}$

The flexibility of less formalized agreement allows differing implementation processes for differing circumstances, something that is much more difficult, if even possible, through

\footnotetext{
${ }^{42}$ Ibid.

${ }^{43}$ Mariely Lopez-Santana, "Introduction" University of Michigan, Comparative Speaker Series $<$ http://sitemaker.umich.edu/comparative.speaker.series/files/chapter1_sept_16.pdf $>$ [accessed on November $17,2006]$, page 6.

${ }^{44}$ Anthony D'Amato and Kristin Engel, supra note 7.
} 
formal arrangements. By opting for a less obligatory approach, soft law can then create agreement where none may have existed otherwise and in this way work to supplement the global governance structure by ensuring an arrangement is made.

The simultaneous use of hard and soft law governance approaches in international relations is undeniable and attempting to divide the two concepts, which inevitably melt into one another, is problematic to say the least. Furthermore, an attempt to uphold one and invalidate the other - if possible - does nothing but limit the choices of extremely diverse parties in finding agreement. It de-legitimizes law in general, not just one type. Each has its place in the international governance structure and without either, international relations and the global community could not operate.

There is no denying that in any international context identification of the demarcation line between law and non-law may constitute a challenging task, given the nature of the international law-making process as frequently informal and essentially decentralized. But any conceptualization of the manifold and complex indicia of international law in terms of 'hard' vs. 'soft' law is inherently problematical.

The concept of 'soft law,' whether by design or by default, is thus apt to advance legal pretensions.

Even if soft law does not harden up, soft law performs important functions, and, given the structure of the international system, we could barely operate without it. ${ }^{45}$

Soft law does not always lead to hard law but both law types acting as legitimate supplements to one another gives strength to international law and the governance structure of international relations.

${ }^{45}$ Anthony D'Amato and Kristin Engel, supra note 7, page 57. 


\section{COMPLIANCE}

The issue of compliance plays a significant role in the debate as to whether soft law is a legitimate facet of international law. Despite the lack of rules and enforcement mechanisms present in hard law agreements, soft law is treated by signatories with an equal amount of respect. ${ }^{46}$ This is due to a variety of political factors, which include a state's reputation with the parties involved in the arrangement as well as in the global community. ${ }^{47}$ Perhaps due to the fact that signatories bestow respect upon both forms of law, compliance becomes a problematic issue for soft and hard law. Certainly, a universal problem cannot keep one form of law outside the purview of legitimacy in the international system when it is a challenge to all forms of international arrangements.

Hard law agreements carry legal consequences for parties who do not meet their obligations. Avoiding such legal consequences is seen as a reason to comply and acts as an enforcement mechanism in hard law, even where proper dispute settlement bodies have not been established. Soft law agreements do not contain such sanctions, however, this has not proven to be cause for states to enter into soft law agreements lightly. As noted by D'Amato and Engel, the evidence suggests signatories to soft law agreements take the negotiation, signing and implementation as seriously as any other type of international agreement.

[I]t is extremely interesting to observe in practice that Member States' delegations approach the negotiation of those provisions with extreme care, just as if they were negotiating treaty provisions. Such behavior suggests that States do not view such "soft" recommendations as devoid of at least some political significance, if not, in the long term, any legal significance. In fact, for a few of these "soft" instruments, some States consider it necessary to formulate reservations to such texts, just as if they were creating formal legal obligations. ${ }^{48}$

\footnotetext{
${ }^{46}$ Douglas Johnston, supra note 5.

${ }^{47}$ Kenneth Abbott et al, supra note 23, page 35.

${ }^{48}$ Anthony D'Amato and Kristin Engel, supra note 7.
} 
Certainly if states are putting a significant amount of time, effort and other resources into the negotiation of soft law agreements, they are bestowing upon them at least some level of legitimacy. Furthermore, if signatories to an agreement are recognizing the arrangement's political importance and respecting its authority as an official document, then they must view the agreement as a legitimate aspect of global governance.

\section{Comparable compliance rates}

Despite the respect given to soft law agreements by their signatories, compliance remains the biggest barrier to the legitimization of soft law as part of the global governance structure. When states sign agreements without the presence of legal obligations, legalists purport adherence to these agreements is less likely to occur because states are not legally obligated to implement the agreements and there are no legal consequences for not complying. However, when the level of compliance with soft law agreements is examined, it appears as though states are as likely to comply with non-binding agreements as they are with binding agreements.

The most revealing recent studies of the "arena" - in particular, studies focusing on the problem of inducing compliance with negotiated commitments - provide persuasive evidence that the record of compliance does not necessarily vary, in otherwise comparable situations, with the softness or hardness of the instruments or of its normative content. ${ }^{49}$

When states put a significant amount of resources into negotiating such arrangements and bestow upon them a level of legitimacy, they take these obligations - even if they are not binding obligations - as seriously as binding rules. In order to negate soft law as a facet of

\footnotetext{
${ }^{49}$ Douglas M. Johnston, supra note 5.
} 
international law on the grounds of poor compliance, it is necessary to prove hard law agreements are complied with more often than soft law agreements. The failure of soft law critics to address which form of rules produces the highest level of compliance is a weakness in the argument for negating soft law as its own facet of international law. With factors other than law coming into play when discussing compliance with international agreements, the presence of binding rules as a necessary component of legitimate international law is not as compelling an argument as it may at first appear.

The World Trade Organization (WTO), for example, has a high level of legalization and uses hard law agreements to govern international economic relations. In addition, disagreements, in the implementation of a signatory's legal obligations, are delegated to a third party dispute settlement mechanism. However, compliance remains an issue, as illustrated below by the Softwood Lumber Dispute between Canada and the United States.

The dispute settlement body is the WTO's dispute settlement mechanism, consisting of all WTO members, which selects a panel to hear the case, accepts or rejects the panel's findings, monitors the implementation of the ruling and has the power to grant retaliation when a country does not comply. ${ }^{50}$ The hard law judicial process of the WTO is seen as necessary to enforce the rules and ensure compliance, ${ }^{51}$ however, there are rulings of the dispute settlement body that are ignored by parties, particularly the party on the losing end of the hearing. The Softwood Lumber dispute between Canada and the United States (US) exemplifies the compliance issues which plague hard law agreements and, by extension,

\footnotetext{
${ }^{50}$ For a full explanation of the WTO's Dispute Settlement Mechanism, see "Understanding the WTO: Settling Disputes, A unique contribution", World Trade Organization $<$ http://www.wto.org/english/thewto_e/whatis_e/tif_e/disp1_e.htm> [accessed on February 9, 2007].

51 "Understanding the WTO: Settling Disputes. A unique contribution," supra note 33.
} 
international law. ${ }^{52}$ Despite two panel rulings [one under the WTO and the other under the North American Free Trade Agreement (NAFTA)], which stated the United States had violated their binding obligations under international law, the United States did not pay retribution for their violation of binding international agreements. In this case, hard law has twofold compliance issues: the initial agreement was breached and the ruling on compensation for the breach is also ignored.

This situation only serves to prove hard law obligations can also be dismissed when a state decides -for whatever political, material or security reasons - the previously agreed legal obligations are no longer beneficial to the state or in line with its current circumstances. Thus, instances of compliance are as much an issue for hard law as they are for soft law. Yet non-compliance with hard law does not de-legitimize it as a facet of international law.

Without evidence to suggest compliance is more of an issue for one governance approach than it is for the other, the application of the compliance argument to de-legitimize soft law when it poses an equal problem for hard law creates a double standard. It simply cannot be used as a legitimate argument for keeping soft law outside the purview of

\footnotetext{
${ }^{52}$ After more than 20 years of trade disputes in the softwood lumber industry, Canada asked for the establishment of a WTO panel in 2001, citing the US placement of illegal tariffs on softwood lumber entering the United States. A WTO panel ruled in favour of Canada and demanded the US pay restitution for the unlawful trade barriers erected. The US did not comply with the panel ruling. Nor did it comply with a similar ruling made by a NAFTA dispute settlement panel siding with Canada. The Government of Canada was under extreme pressure to settle the dispute as it was wreaking havoc on Canada's lumber industry, impacting the economy and hurting relations between the nations. In 2006 the Canadian and American governments negotiated a bilateral agreement on the softwood lumber issue and Canada was paid restitution, though only $80 \%$ of what was owed according to the WTO's dispute settlement body. The extent to which politics played a role in this particular dispute is not the focus of this paper, however, its influence cannot be ignored in either the initial tariff implementation, failure to reach agreement, or in the final negotiations. Where the original hard law agreement as well as legal economic institutions with dispute settlement mechanisms failed to ensure compliance, diplomacy, negotiation and conciliatory talks resolved the issue. The full extent of the Softwood Lumber Agreement is not outlined in this paper. The following resources were consulted for the overview of the dispute and can be referenced for further information: "Indepth: Softwood Lumber Dispute", (dated August 23, 2006) <http://www.cbc.ca/news/background/softwood_lumber/> [accessed on November 16, 2006]; "Softwood Lumber", Export and Import Controls, Foreign Affairs and International Trade Canada (last updated October $11,2006)<\mathrm{http}: / / \mathrm{www}$.international.gc.ca/eicb/softwood/intro-en.asp > [accessed on November 16, 2006]; "Dispute Settlement", Foreign Affairs and International Trade Canada (last updated November 11, 2006) $<$ http://www.dfait.maeci.gc.ca/tna-nac/dispute-en.asp $>$ [accessed on November 16, 2006].
} 
international law and thus soft law should be considered a legitimate part of the governance structure.

\section{The role of politics}

Despite the fact that soft law agreements do not carry legal obligations, the political pressure to conform can be just as coercive as having a legal obligation with which to comply. ${ }^{53}$ Politics and law are difficult, if not impossible to separate, especially in regards to international agreements. Politically, the repercussions for not following soft law are seen as great as the legal repercussions for not following hard law. As Harmut Hillgenberg points out,

...the fact that, when assessed realistically, the difference between a treaty and the binding 'political' effect of a non-treaty agreement is not as great to a politician as is often thought may also play a role in the decision to opt for a non-treaty form of agreement. ${ }^{54}$

With similar political effects, the hardness or softness of law is more of a technicality rather than a determining factor when the political party in power is determining whether or not their state will comply with the said agreement.

There are legitimate concerns surrounding a state's image in the international community should they decide not to comply with agreements of any sort and these concerns act as an enforcement mechanism and carry weight when complying with soft law agreements. Abbott, Keohane, Moravcsik, Slaughter and Snidal note,

Compliance with rules occurs for many reasons other than their legal status. Concern about reciprocity, reputation, and damage to valuable state

${ }^{53}$ Harmut Hillgenberg, supra note 21, page 502.

${ }^{54}$ Ibid. 
institutions, as well as other normative and material considerations, all play a role. $^{55}$

Political influences, reputation and possible reciprocity, as variables in a party's decision to comply with soft law, cannot be ignored.

\section{THE LEGITIMACY OF INTERNATIONAL LAW}

The question has been raised as to whether international law itself is enforceable, whether it should even be considered law due to its lack of "police" to enforce the rules and ensure compliance with legal obligations. International organizations, such as the United Nations, do not have an international police force to enforce states' legal obligations, despite issues of non-compliance. This lack of an enforcement mechanism does not de-legitimize the laws observed by its members and this organization remains a legitimate part of the governance structure. As Abbott and Snidal point out,

...international regimes do not even attempt to establish legal obligations centrally enforceable against states. Yet it is erroneous to conclude that the 'formal legal status' of international agreements is therefore meaningless. ${ }^{56}$

Thus, if we are not dismissing international law, in general, due to various enforcement and compliance issues, then negating soft law on this basis is flawed decision-making.

\section{FACTORS IMPACTING GOVERNANCE}

Compliance poses a problem for almost every aspect of rule-making, no matter the form or institutionalization of those rules. The logical question to ask then would be why

\footnotetext{
${ }^{55}$ Kenneth W. Abbott et al, supra note 23, page 35.

${ }^{56}$ Kenneth W. Abbott and Duncan Snidal, "Hard and Soft Law in International Governance", International Organization.(2000) Vol 54, No 3, page 426.
} 
nations make and follow international agreements at all? ${ }^{57}$ The answer, equally as logical, is that states are aware there are benefits to cooperation. In order to maximize these benefits, states choose their approaches to governance wisely, acutely aware of present, as well as future repercussions for their actions. It is a political game with many factors impacting a state's choice of governance options.

\section{SOVEREIGNTY}

State sovereignty is, arguably, one of the most important elements of international relations. Arms are accumulated, wars are fought, genocides conducted and ignored for the sake of sovereignty. It is also a major deterrent for signing a legally binding contract. While hard law has certain benefits, it is not always desirable for states as it limits their domestic policy choices. Goldstein, Kahler, Keohane and Slaughter point out the influence of sovereignty and note, "Legalization, a particular form of institutionalization, represents the decision in different issue-areas to impose international legal constraints on governments." Hard law arrangements create limitations on state action, limitations that are not imposed by soft law agreements. Often that is enough reason to sign an accord rather than a legally binding contract. ${ }^{59}$

\footnotetext{
${ }^{57}$ A sample of authors commenting on the topic of why states adhere to international agreements include, but are not limited to Harold Hongju Koh, "Why Do Nations Obey International Law?", The Yale Law Journal (1997) Vol 106, No 8; Abram Chayes and Antonia Handler Chayes, The New Sovereignty: Compliance with International Regulatory Agreements (Cambridge: Harvard University Press, October 1998); Thomas M. Franck, Fairness in International Law and Institutions (Gloucestershire: Clarendon Press, January 1998). ${ }^{58}$ Judith L.Goldstein, Miles Kahler, Robert O. Keohane, Anne-Marie Slaughter, "Introduction: Legalizations and World Politics", in Judith L. Goldstein, Miles Kahler, Robert O. Keohane, Anne-Marie Slaughter, eds. Legalization and World Politics (Cambridge: MIT Press, May 2001), page 2.

${ }^{59}$ The limitations associated with hard law are cited as influencing states to opt for a soft law agreement by Kenneth W. Abbott and Duncan Snidal, "Hard and Soft Law in International Governance", International Organization (2000) Vol 54, Issue 3, pages 435 and 444; Anthony D'Amato and Kristin Engel, International Environmental Law Anthology (Ohio: Anderson Publishing Company, 2001) $<$ http://anthonydamato.law.northwestern.edu/IELA/Intech05-2001-edited.pdf $>$ [accessed on November 3, 2006], page 56 .
} 
Complying with - and thus legitimizing - soft law agreements works to protect state sovereignty because by legitimizing accords and helping to configure them into the global governance structure, states would be under less pressure to sign legally binding obligations. Douglas Johnston notes the impact of soft law on sovereignty and examines the importance of the correlation in a state's future sovereignty concerns.

...future compliance with international soft law - a matter of state choice - is likely to continue to be driven by institutional and constructivist forces, so long as globalization and democratization continue. States are likely to retain their legal sovereignty even in the face of global pressures so long as they remain the sole authoritative source for compliance decisions. ${ }^{60}$

Due to sovereignty concerns, states are likely to continue to sign and comply with soft agreements as it quells fears - legitimate or not - created by legally binding obligations. The decision to choose soft law in order to maintain state sovereignty is a very strategic one, as it protects a state's status in the global game of international relations.

\section{POLITICAL STRATEGY}

According to some scholars, the selection of the appropriate - and most beneficial law type, in Asia specifically, is dictated by cultural preferences. ${ }^{61}$ There are several problems with this theory. First of all, "Asia" is a diverse and multi-faceted region with numerous cultural differences. Suggesting the entire region rejects more legalized agreements due to cultural preferences, does not take this diversity into account, and contains, as its foundation, an inherently racist sentiment. Secondly, these theories do not take into account the variation among international agreements entered into by actors in the

\footnotetext{
${ }^{60}$ Douglas M. Johnston, supra note 5, page 711.

${ }^{61}$ Miles Kahler, supra note 18, page 561-562.
} 
region. Parties in the Association of South East Asian Nations (ASEAN) grouping, for example, are negotiating regional economic cooperation with neighbouring nations such as China, Japan and Korea without creating formal hard law agreements. However, these states are party to the formal obligations of the WTO. Thus, the choice of legalization for the Asian neighbours - which will be fully discussed in the following chapter - is purely strategic and is used to achieve the economic aims of the parties while accounting for various political factors, which influence economic decision-making.

...legalized institutions are primarily a means to other ends... The national choice of legalization in a particular context, then, results from a calculus that legalized institutions serve those goals, even when costs (particularly sovereignty costs) are taken into account. The choice for or against legalized institutions is also strategic, since it will be influenced by the competing strategies and capabilities of other actors in particular institutional settings. ${ }^{62}$

While the preference for a certain type of law, be it hard or soft, is widely discussed among international relations and international law scholars ${ }^{63}$, in practice, it would appear that the parties dictate on an issue-by-issue basis what works for finding agreement in a particular issue area.

States act according to their strategic interests, of which maintaining sovereignty is but one. After weighing the costs and benefits of hard and soft law, they choose the situation

\footnotetext{
${ }^{62}$ Miles Kahler, supra note 18, page 562.

${ }^{63}$ The debate surrounding the desirability as well as the costs and benefits of both hard and soft law is of fundamental importance to this paper. Notable authors in this subject area include C. M. Chinkin, "The Challenge of Soft Law: Development and Change in International Law", The International and Comparative Law Quarterly (October 1989) Vol 38, No 4; Harmut Hillgenberg, "A Fresh Look at Soft Law", Economic Journal of International Law (1999) Vol 10, No 3; Kenneth W. Abbott, Robert O. Keohane, Andrew Moravcsik, Anne-Marie Slaughter, and Duncan Snidal, "The Concept of Legalization", in Judith L. Goldstein, Miles Kahler, Robert O. Keohane, Anne-Marie Slaughter, eds. Legalization and World Politics (Cambridge: MIT Press, May 2001).
} 
best suited to their future goals and current needs. ${ }^{64}$ Thus, while there is a move towards rules-based governance, these rules do not necessarily need to be - and most often will not be - cemented obligations if that law type is not seen as the most beneficial.

\section{GOVERNANCE MOVING FORWARD}

In order to reach agreement on heavily politicized international issues, it is sometimes necessary to leave specific obligations out of the negotiation. Signatories are often apprehensive about creating rules that may impact their domestic situation, reduce sovereign decision-making and lead to consequences when circumstances forbid compliance with agreements. Staying away from specific rules and obligations can create agreement on important international issues where there would be none otherwise. ${ }^{65}$ With some international financial institutions mandating a conciliatory approach to decision-making and others using an overall soft law approach, there are options available that do not depend on hard rules or enforceable obligations to be considered a valid form of agreement under international law.

Certainly, rules-based governance is a major aspect of international economic relations and the preferred form of governing global activities, but the extent to which these rules are developed varies across the multitude of institutions and agreements attempting to create understanding on intra and international issues.

The use of soft law may become more prevalent as globalizing forces continue to connect various parties in partnerships, economic and otherwise. The use of less formal arrangements makes these agreements easier to reach and indeed creates agreement where

\footnotetext{
${ }^{64}$ Miles Kahler, supra note 18, page 550, 562 and 568; Kenneth W. Abbott and Duncan Snidal, supra note 56, page 423 .

${ }_{65}$ Joseph Gold, supra note 11.
} 
none may have existed otherwise. This alone should validate soft law as its own facet within the governance structure of economic relations.

It does not follow that international legalization will continue at the same rate, or that the apparent tendency toward (somewhat) harder legalization will continue. Indeed, a central part of our argument is that states and nonstate actors can achieve many of their goals through soft legalization that is more easily attained or even preferable.

In this light, we argue vigorously against those who discount international legalization because it is so often soft. Soft law is valuable on its own, not just as a steppingstone to hard law. Soft law provides a basis for efficient international "contracts," and it helps create normative "covenants" and discourses that can reshape international politics. International legalization in all its forms must be considered one of the most significant institutional features of international relations. ${ }^{66}$

The international community uses a rules-based approach to governance as it deals with parties from unfamiliar cultures, political circumstances and legal systems. The purpose of enacting rules and creating a rules-based governance structure is to provide predictability when getting into relationships with parties you do not know. The level to which rules are formalized can - and does - vary from agreement to agreement as well as organization to organization, but it does so without eroding legal legitimacy.

The enforcement mechanism, or dispute settlement body, within the WTO does not ensure full compliance with the rules of the WTO and there is no international police force to ensure compliance with UN declarations, yet international law still exists and is seen as a legitimate form of global governance. Adapting that governance structure to recognize the role of soft law is not only necessary but logical. Soft law already plays an enormous role in governing international relations, whether it is recognized as doing so or not. Its recognition

${ }^{66}$ Kenneth W. Abbott and Duncan Snidal, supra note 56, page 456. 
will simply place it in the toolbox of policy options, bestowing upon it legitimacy and allowing nations to select arrangements and associations which are most beneficial to their development. East Asia currently has soft law prominently featured in their toolbox as they attempt, knowingly or unknowingly, to remodel economic governance of the finance sector. 
Chapter 3:

Case Study: East Asian Financial Markets 
Soft law should be considered a valid aspect of international law as developing regional financial cooperation in East Asia is giving it legitimacy. The consultative history and standard operating procedures of ASEAN make a soft law approach to governance a natural choice and its expansion into international regulation is likely because of the role it is playing and the success it is experiencing in facilitating regional financial cooperation.

This case study outlines the development of finance sector governance in East Asia. This sector is largely unregulated but East Asian partners are cooperating to develop a framework that will bring stability to the sector and address the problems of the current economic governance structure. These partners are using soft law to develop this framework and since the finance sector is not currently governed by heavily legalized institutions or international agreements, the form of governance used regionally can establish the groundwork for any international initiatives which may develop. The successful utilization of soft law in governing the finance sector in East Asia can be seen as legitimizing this approach to governance. Whether governance of the finance sector remains based in soft law or whether soft law commitments eventually translate into legal obligations, a soft law approach to governance may eventually be accepted as a facet of international law due to its success in facilitating cooperation in Asia. This will naturally impact international relations and global governance as they are currently conducted. The ongoing initiatives in East Asia are opening up the international legal framework to a new approach to governing the finance sector, an approach which can be seen as legitimizing soft law as a facet of law and reforming economic governance.

This chapter begins by briefly recounting events surrounding the Asian Crisis. It then outlines cooperative initiatives the nations of East Asia have undertaken to facilitate finance 
sector regulation, using approaches to governance outside those accepted by international law. These arrangements include, but are not limited to, the Asian Monetary Fund, the Manila Framework Group, the New Miyazawa Initiative and the Chiang Mai Initiative.

The purpose of this chapter is to provide a working example of soft law in facilitating cooperation. Choosing this approach to governance has thus far proven successful for the Asian neighbours and its continued success will promote financial cooperation, validate soft law as part of the legal structure and influence the composition of future international initiatives attempting to regulate the finance sector.

The East Asian response to the regional crisis of 1997-1998 has created a platform for dialogue and collaboration among historically divergent interests. This is a positive step towards stability, and most importantly for financial markets, predictability in the region, which through continued cooperation has promising economic (and political) potential. East Asia's soft law approach to formulating financial agreements is adding a new method of cooperation to international relations impacting international law and changing economic governance.

\section{THE CRISIS}

In the early 1990 s the International Monetary Fund (IMF) added financial liberalization to its mandate and encouraged many Asian economies to liberalize their financial sector. When markets were opened up, massive inflows of foreign capital entered Thailand, concentrating in the stock market and real estate market, fueling asset-inflation. By 
1995 , this short-term debt totaled $\$ 41$ billion (US) of Thailand's $\$ 83$ billion foreign debt. ${ }^{67}$

At this time, apprehension surrounding these inflows was basically non-existent because

many of the financial transactions were conducted by private actors and according to the international financial institutions and basic neo-liberal economic theory, market forces are self-correcting; there was no need to worry. However, investors began to do just that in mid1997 when indicators such as a large current account deficit, a growth rate near zero and a foreign debt calculated as high as $\$ 89$ billion surfaced due to impending repayment guarantees. Investors fled at lightning speed, causing devaluation of the Thai Baht. The same behaviour was found in investors of other Asian nations as similar macroeconomic indicators in Manila, Kuala Lumpur and Jakarta created fear of devaluation of other currencies; investment stampeded out of the region. The result of poor financial infrastructure in partnership with speculative investment was devastating for the region and hence is known as the Asian Crisis. ${ }^{68}$

It is important to note here that every nation in crisis at the time had liberalized its financial markets and doubt concerning the economic governance structure's capacity to prevent and contain crises was rising. This lack of confidence, if anything, increased as policy prescriptions were dispersed by the International Monetary Fund. ${ }^{69}$

\footnotetext{
${ }^{67}$ Walden Bello, "The End of a 'Miracle.' Speculation, Foreign Capital Dependence and the Collapse of the Southeast Asian Economies", The Multinational Monitor (January/February 1998) Vol 19, No 1 and 2 $<$ http://www.hartford-hwp.com/archives/54/124.html> [accessed on February 25, 2005].

${ }^{68}$ Due to time constraints and the focus of this paper, a full description of the complexities of the Asian Crisis was not examined here. For further research on this issue see, for example, Walden Bello, "The End of a 'Miracle", Speculation, Foreign Capital Dependence and the Collapse of the Southeast Asian Economies", The Multinational Monitor (January/February 1998) Vol 19, No 1 and 2; Robert Wade, "From 'miracle' to 'cronyism': explaining the Great Asian Slump", Cambridge Journal of Economics (November 1998) Vol 22, No 6; Joseph Stiglitz, "More Instruments and Broader Goals: Moving Towards the Post-Washington Consensus", UNU World Institute for Development Economics Research, 1998 Wider Annual Lectures (1998); Yung Chul Park and Yunjong Wang, "The Chiang Mai Initiative and Beyond", The World Economy (January 2005) Vol 28, No 1; Chalongphob Sussangkarn, "East Asian Monetary Cooperation", Thailand Development Research Institute $<$ http://www.info.tdri.or.th/reports/unpublished/chals.pdf $>$ [accessed on March 2, 2005]. ${ }^{69}$ The weaknesses in economic governance, mentioned here, will be fully discussed in Chapter 4.
} 


\section{RESPONDING TO CRISIS}

The Asian Crisis was the shock needed to jumpstart what some describe as Asian regionalization. It was a turn of events, which called to action domestic governments in facilitating cooperation and highlighted the connection among nations within East Asia. The impact of the crisis coupled with the disappointing results surfacing from the initiatives of the international financial institutions influenced them to look within themselves for solutions to regional economic problems. ${ }^{70}$ The following is a review of some of these proposed solutions and their place in the development of a regional legal framework and an evolving economic governance structure.

\section{ASIAN MONETARY FUND (AMF)}

Directly following the devastating crisis that hit Asia, the Japanese government took the lead in outlining an institutional framework for regional economic cooperation, titled, the Asian Monetary Fund (AMF). ${ }^{71}$ The idea was introduced in September 1997. The fund was to establish a $\$ 100$ billion account to provide liquidity to nations in crisis, half of which was to be provided by Japan with the other half coming from other participating countries in the region. Membership was to include the Peoples' Republic of China, Hong Kong, Japan, Korea and Taipei. The fund was to promote financial cooperation, policy coordination and

\footnotetext{
${ }^{70}$ Yunjong Wang, "Financial Cooperation and Integration in East Asia", Journal of Asian Economics (October 2004) Vol 15, Issue 5, page 939.

${ }^{71}$ For the information used within this section or for further information surrounding the Asian Monetary Fund see for example, Shaun Narine, "ASEAN and the Idea of an "Asian Monetary Fund", The $2^{\text {nd }}$ ASEAN Reader, compiled by Sharon Siddique and Sree Kumar, Institute of Southeast Asian Studies, Singapore (2003); Yu Yongding, "On East Asian Monetary Cooperation", Institute of World Economics and Politics: Chinese Academy of Social Sciences <http://www.iwep.org.cn/pdf/02wp_rcif.pdf $>$ [accessed on March 2, 2005]; Ramgopal Agarwala and Brahm Prakash, "Regional Cooperation in Asia: Long-term Progress, Recent Retrogression, and the Way Forward", Asian Development Bank: ERC Working Paper Series No 28 (October 2002); Chalongphob Sussangkarn, "East Asian Monetary Cooperation", Thailand Development Research Institute $<$ http://www.info.tdri.or.th/reports/unpublished/chals.pdf>; Pradumna B. Rana, "Monetary and Financial Cooperation in East Asia: The Chiang Mai Initiative and Beyond", Asian Development Bank: Working Paper No 6 (February 2002).
} 
dialogue while providing access to reserves in order to defend against financial crises and speculative attacks on currencies within the region. As suggested by $\mathrm{Yu}$,

The most essential element of the proposed AMF is that of providing emergency financial support to would-be crisis countries. Compared with the IMF's rescue packages, the funds provided by the AMF would be more speedy and the conditions for providing funds less harsh and more in line with the Asian way. ${ }^{72}$

However, it was this very element, interpreted as a threat to the international financial system and its institutions, that helped dismantle the suggestion for an Asian Monetary Fund. The primacy of the International Monetary Fund as the financial institution dispersing optimal policy advice for economic development was seen to be contested by this regional initiative. $^{73}$

The international financial institutions and the US Treasury Board promptly shelved the idea of an Asian Monetary Fund as it was seen as a challenge to the leadership of the International Monetary Fund, creating a double standard between an AMF and the IMF. There were concerns surrounding an Asian Monetary Fund ultimately rejecting the policies of the International Monetary Fund and following an "Asian model of development" due to comments from the former vice-minister for international affairs in Japan, Eisuke Sakakibara, who "explicitly argued that the AMF would defend the Asian model.",74

The "Asian model" was associated with industrial policy and government intervention, which caused tension with the International Monetary Fund's market-oriented

\footnotetext{
${ }^{72}$ Yongding Yu, "On East Asian Monetary Cooperation", Institute of World Economics and Politics, Chinese Academy of Social Sciences <http://www.iwep.org.cn/pdf/02wp_rcif.pdf $>$, [accessed on March 2, 2005], page 3. The "Asian way" referenced here is discussed in Chapter 2 and refers to cooperation based on consultation and consensus.

${ }^{73}$ Yunjong Wang, supra note 70, page 942.

${ }^{74}$ Shaun Narine, "ASEAN and the Idea of an "Asian Monetary Fund", The $2^{\text {nd }}$ ASEAN Reader, compiled by Sharon Siddique and Sree Kumar, Institute of Southeast Asian Studies, Singapore (2003), page 256.
} 
prescriptions. Any institution which would challenge the policies of the international financial institutions was of course unwanted by the international community ${ }^{75}$ Full disclosure of plans for the AMF did not have time to surface and indeed procedural and institutional details were not developed at the time of the unveiling. The fact that definite roles and mandates were not properly defined created nervousness in the international community as to the purpose and future prospects of the AMF. ${ }^{76}$ Many proponents of the initiative argued, "A regional monetary fund would provide a means of defense, in addition to IMF lending facilities, against financial crisis in East Asia," (emphasis added). ${ }^{77}$ But in the end, it was the uncertainty surrounding the Asian Monetary Fund and the possibility of future developments that contributed most to its rejection.

\section{MANILA FRAMEWORK GROUP (MFG)}

In order to replace the defeated idea of an Asian Monetary Fund and indeed to learn from its failure, the Manila Framework Group was established in November 1997 for the purpose of providing regional surveillance. ${ }^{78}$ The Manila Framework Group is a surveillance mechanism to monitor economies in order to enhance predictability of market flows and prevent another crisis. The Group contains 14 countries from the Pacific region and thus is

\footnotetext{
${ }^{75}$ Yongding $\mathrm{Yu}$, supra note 72 , page 8.

${ }^{76}$ Chalongphob Sussangkarn, "East Asian Monetary Cooperation." Thailand Development Research Institute $<$ http://www.info.tdri.or.th/reports/unpublished/chals.pdf $>$ [accessed on March 2, 2005],.page 3.

${ }^{77}$ Pradumna B. Rana, "Monetary and Financial Cooperation in East Asia: The Chiang Mai Initiative and Beyond", Asian Development Bank, Working Paper No 6 (February 2002), page 5.

${ }^{78}$ For the information used within this section or for further information surrounding the Manila Framework Group see for example, Ramgopal Agarwala and Brahm Prakash, "Regional Cooperation in Asia: Long-term Progress, Recent Retrogression, and the Way Forward", Asian Development Bank: ERC Working Paper Series No 28 (October 2002); Pradumna B. Rana, "Monetary and Financial Cooperation in East Asia: The Chiang Mai Initiative and Beyond", Asian Development Bank: Working Paper No 6 (February 2002); President Tadao Chino, "Monetary and Financial Cooperation in East Asia: Lessons from Europe", Remarks at the 4th ASEAN Finance Ministers' Meeting, Copenhagen, Denmark (July 5, 2002) $<\mathrm{http}: / /$ www.adb.org/Documents/Speeches/2002/ms2002073.asp> [accessed on March 2, 2005]; "Regional Financial Cooperation in East Asia: The Chiang Mai Initiative and Beyond", Bulletin on Asia-Pacific Perspectives $<$ http://www.unescap.org/pdd/publications/bulletin2002/ch8.pdf $>$ [accessed on March 2, 2005].
} 
not segregated to Asian nations. It adds nothing substantially new to the legal framework and is "largely defunct in practice." management within the East Asian region, but is completely subsidiary to the International Monetary Fund. Representatives of member countries' finance ministries and central banks, along with officials from the international financial institutions provide surveillance reports and schedule semiannual meetings.

Such an initiative is seen as acceptable by the international community because the international community is directly involved. The Asian Monetary Fund was to be established in order to aid only Asian nations in times of crisis and that put Asian nations in the driver's seat, making all decisions concerning the Fund. The Manila Framework, on the other hand, encompasses nations bordering the Pacific including the Western nations Australia, Canada and the United States of America and logically all parties within the Group have input as to any action taken. Thus, decisions require negotiations with the aforementioned market-oriented, industrialized nations.

In addition to the inclusion of the Western world, the Manila Framework is accepted due to its ability to complement the workings of the International Monetary Fund. The international financial institutions are heavily represented at the Group meetings to ensure it supplements the work of the International Monetary Fund in areas such as surveillance, financing and the development of international standards and codes. This ensures any developments within the Manila Framework Group are aligned with the international structure, or would, at the very least, put pressure on the Group to move in that direction. In

\footnotetext{
${ }^{79}$ Ramgopal Agarwala and Brahm Prakash, "Regional Cooperation in Asia: Long-term Progress, Recent Retrogression, and the Way Forward", Asian Development Bank: ERC Working Paper Series No 28 (October 2002), page 25 .
} 
this way, the IMF maintains its leadership role and the international community's

development policies and overall approach to governance is not challenged.

It simply reinforces the status quo governance structure, which has been "largely defunct" in controlling capital flows and quelling financial crises.

NEW MIYAZAWA INITIATIVE (NMI)

Yet another Japanese initiative was introduced in October 1998, known as the New Miyazawa Initiative. ${ }^{80}$ Japanese Minister of Finance, Miyazawa, implemented the bilateral support mechanism to assist Asian economies suffering from currency crises, while aiding in the stabilization of financial markets. Packages were to include $\$ 30$ billion in untied loans with half going to medium to long-term financing assistance and the other half providing short-term capital support. While it left open the possibility for future lending, the Japanese Government completed its stated role of providing post-crisis financial assistance to its regional neighbours in 2000 , with $\$ 21$ billion (two thirds of the amount originally pledged) being dispersed to Indonesia ( $\$ 2.93$ billion), South Korea ( $\$ 8.35$ billion), Malaysia ( $\$ 4.35$ billion), the Philippines ( $\$ 2.50$ billion) and Thailand ( $\$ 2.87$ billion). ${ }^{81}$ Initiative loans were meant to help with debt restructuring, strengthen the social safety net, restructure the economy, and facilitate trade finance and assistance to small and medium-size enterprises.

\footnotetext{
${ }^{80}$ For further more information on the New Miyazawa Initiative see, for example, Yongding Yu, "On East Asian Monetary Cooperation", Institute of World Economics and Politics: Chinese Academy of Social Sciences $<$ http://www.iwep.org.cn/pdf/02wp_rcif.pdf $>$ [accessed on March 2, 2005]; Ramgopal Agarwala and Brahm Prakash, "Regional Cooperation in Asia: Long-term Progress, Recent Retrogression, and the Way Forward", Asian Development Bank: ERC Working Paper Series No 28 (October 2002); "Regional Financial Cooperation in East Asia: The Chiang Mai Initiative and Beyond", Bulletin on Asia-Pacific Perspectives $<$ http://www.unescap.org/pdd/publications/bulletin2002/ch8.pdf> [accessed on March 2, 2005]; "Miyazawa Initiative wraps up, providing \$21 bil", Asian Economic News (dated March 6, 2000) $<$ http://www.findarticles.com/p/articles/mi_m0WDP/is_2000_March_6/ai_59998149> [accessed February 27, 2007].

81 "Miyazawa Initiative wraps up, providing \$21 bil", Asian Economic News (dated March 6, 2000) $<$ http://www.findarticles.com/p/articles/mi_m0WDP/is_2000_March_6/ai_59998149> [accessed February 27, 2007].
} 
The key issue with this initiative was its untied loans, completely separate from the International Monetary Fund and its subsequent conditionality, yet allowed due to their bilateral nature. Unlike the multilateral Asian Monetary Fund, the New Miyazawa Initiative represented bilateral loan agreements between Japan and the country in crisis. In this way, it was not seen as a threat to the supremacy of the International Monetary Fund and it did not require the establishment of an institution.

The lack of loan conditionalities within these agreements was an interesting, and perhaps surprising, element to the Initiative. The stated aims of the New Miyazawa Initiative, however, followed the same lines as the policy prescriptions of the International Monetary Fund as it promoted debt restructuring and repayment, worked to stimulate the economy and attempted to provide stability to financial markets.

In the New Miyazawa Initiative a compatible relationship was found between international and regional efforts. In this arrangement, the international legal structure remained the overarching structure for economic development but the New Miyazawa Initiative still provided the much needed additional liquidity and financial support to countries in crisis. Help coming from a state within the region addressed all the issues of speed and appropriateness associated with aid packages yet had the full support of the international financial institutions and the United States, as it maintained a market-orientation and added to the stability of international markets. This Initiative laid the groundwork and in essence was a boundary test for the establishment of the Chiang Mai Initiative. 
CHIANG MAI INITIATIVE (CMI)

The conception and continuous development of the Chiang Mai Initiative is seen as the most successful and most promising framework for economic cooperation put forth thus far in the short history of East Asian regionalization. The Association of Southeast Asian Nations (ASEAN) in cooperation with Japan, China and Korea make up the ASEAN +3 coalition of countries committed to this project. The beehive of activity surrounding the Initiative reflects its ability to bring historical rivals under the 'ASEAN +3' grouping, produce bilateral regional agreements, and also highlights its potential for future economic cooperation and institutional development. ${ }^{82}$

\section{The fundamentals}

In May 2000, at the annual meeting of the Asian Development Bank, the Chiang Mai Initiative was established by the finance ministers of the ASEAN+3 nations to strengthen policy dialogue and regional cooperation, provide support for nations experiencing liquidity problems and ultimately prevent the occurrence of another financial crisis and its contagious effect in the region. As noted by Rana, the Chiang Mai Initiative ultimately calls for,

\footnotetext{
${ }^{82}$ The technical components of the Chiang Mai Initiative, ASEAN Swap Arrangement and Bilateral Swap Arrangement were retrieved from the following non-extensive list of sources: C. Randall Henning, East Asian Financial Cooperation (Washington, D.C.: Institute for International Economics, September 2002); Pradumna B. Rana, "Monetary and Financial Cooperation in East Asia: The Chiang Mai Initiative and Beyond", Asian Development Bank: Working Paper No 6 (February 2002); "Regional Financial Cooperation in East Asia: The Chiang Mai Initiative and Beyond", Bulletin on Asia-Pacific Perspectives

$<$ http://www.unescap.org/pdd/publications/bulletin2002/ch8.pdf $>$ [accessed on March 2, 2005]; Ramgopal Agarwala and Brahm Prakash, "Regional Cooperation in Asia: Long-term Progress, Recent Retrogression, and the Way Forward", Asian Development Bank: ERC Working Paper Series No 28 (October 2002); Yongding $\mathrm{Yu}$, "On East Asian Monetary Cooperation", Institute of World Economics and Politics, Chinese Academy of Social Sciences <http://www.iwep.org.cn/pdf/02wp_rcif.pdf $>$ [accessed on March 2, 2005]; Chalongphob Sussangkarn, "East Asian Monetary Cooperation", Thailand Development Research Institute $<$ http://www.info.tdri.or.th/reports/unpublished/chals.pdf $>$ [accessed on March 2, 2005]; Yung Chul Park and Yunjong Wang, "The Chiang Mai Initiative and Beyond", The World Economy (January 2005) Vol 28, No 1; Yunjong Wang, "Financial Cooperation and Integration in East Asia", Journal of Asian Economics (October 2004) Vol 15, Issue 5.
} 
(i)An expanded ASEAN Swap Arrangement that would include all ASEAN countries and a network of bilateral swap and repurchase agreement facilities among ASEAN countries, PRC, Japan, and Korea.

(ii) Use of the ASEAN+3 framework to promote the exchange of consistent and timely data and information on capital flows.

(iii) Establishment of a regional financing arrangement to supplement existing international facilities.

(iv) Establishment of an appropriate mechanism (early warning system) that could enhance the ability to provide sufficient and timely financial stability in the East Asian region. ${ }^{83}$

It is an ambitious undertaking. However, it is seen by many as the most promising proposal to come out of the region thus far. It uses a soft law approach to governing the finance sector keeping in line with the Asian way of negotiation and many proponents note the potential carried by the Initiative and the opportunity it provides for future cooperation.

The basic components of the Initiative are the expanded ASEAN Swap Agreements (ASA) and the creation of a bilateral swap network and repurchase agreement. The ASA was initially developed in 1977 in order to alleviate the short-term liquidity problems of member states, which at the time included Indonesia, Malaysia, Philippines, Singapore, and Thailand. In November 2001 under the Chiang Mai Initiative, the amount of the ASA was expanded from $\$ 200$ million to $\$ 1$ billion and coverage included all ASEAN member states.

Governments can draw up to twice the amount they originally pledged and the maturity of swaps is six months with the possibility of rolling over that arrangement for up to another six months, unconditionally.

The purpose of the Bilateral Swap Arrangements (BSA) and Repurchase Agreement is to provide short-term liquidity assistance in the form of country to country swaps involving all nations of the ASEAN+3 grouping. The amount is decided through negotiation, and

${ }^{83}$ Pradumna B. Rana, supra note 77 , page 8. 
borrowing is usually in the form of US dollars. Up to ten percent of those swaps can be drawn without being subject to the conditionality of the International Monetary Fund, which is necessary for the realization of the full amount of the arrangement. This limit is expected to increase once the region develops a fully functioning surveillance arrangement. As of May 2006, 16 BSAs have been negotiated amounting to $\$ 75$ billion (US), almost doubling the size of swap arrangements from the previous year. ${ }^{84}$

\section{The potential}

While many critics repeatedly point to the monetary value of the current BSAs and highlight their insignificance in relation to IMF bailouts during the crisis of 1997-1998, the ability of the nations within East Asia to raise funds as necessary need not be questioned. The region holds an enormous amount of foreign reserves. Sussangkarn explains how,

In some aspects, the combined financial clout of the group is quite sizeable. The combined foreign reserves of the group amounted to over US $\$ 900$ billion in 2000 , accounting for about $45 \%$ of the foreign reserves for all the countries in the world. The group also has a combined current account surplus of over US $\$ 200$ billion in 2000 . With such a large size of reserve assets and saving surplus, the group should try to gain much more leverage in shaping the global financial system. ${ }^{85}$

Thus, not only does East Asia have the ability to increase the amount of liquidity assistance, it has the potential, as seen by many, to take a substantial place in the international economic

\footnotetext{
84 "Regional Financial Cooperation among ASEAN+3", Japan Ministry of Finance $<$ http://www.mof.go.jp/english/if/regional_financial_cooperation.htm> [accessed on January 24, 2007].

${ }^{85}$ Chalongphob Sussangkarn, "East Asian Financial Cooperation: An Assessment of the Rationales", Thailand Development Research Institute <http://www.info.tdri.or.th/reports/published/po8.pdf >, [accessed on March 2, 2005], page 16.
} 
system. This placement will increase their ability to influence the economic governance structure, possibly opening it up to different options for agreement-making.

The Chiang Mai Initiative and its supplementary relationship to the international economic framework have contributed to the passive stance of the IMF in relation to East Asia's current attempt at economic cooperation. The linkage of Bilateral Swap Arrangements to IMF conditionality is a major factor in the international community's acceptance of the Initiative, when it has stood in opposition to others. As Park and Wang point out,

At present, the CMI does not require a new institution like the proposed AMF. And it is also tightly linked to IMF conditionalities. In this regard, the CMI and its follow-up implementation are acceptable to many detractors of the regional monetary fund. ${ }^{86}$

Through linkages to IMF conditionality the international community is appeased, yet some members of the ASEAN+3 grouping do not see this as a beneficial arrangement considering the harsh nature of the international financial institution's prescribed policies. All members have agreed to the terms, however, only in order to avoid delays in the launching of the Initiative. Apprehensive members signed on in the hopes that once the Initiative has left its infancy stage, independence may surface. Having said that, they are very much aware the International Monetary Fund lent its approval to the Initiative because of its supplementary nature to the international economic framework. Malaysia has been the state most vocally opposed to any regional initiative being tied to IMF conditionality. ${ }^{87}$ Other nations share the goal of independence which they feel will come once the Chiang Mai Initiative becomes a more institutionalized framework; eventual independence is almost impossible to avoid once

\footnotetext{
${ }^{86}$ Yung Chul Park and Yunjong Wang, "The Chiang Mai Initiative and Beyond", The World Economy_(January 2005) Vol 28, No 1, page 92.

${ }^{87}$ Ibid., page 95 .
} 
a regional initiative designed to promote cooperation and integration is created. ${ }^{88}$ For now, East Asian regionalization develops under the auspices of IMF conditionality with pledges to increase the ten per cent stipulation within bilateral swap arrangements as soon as a surveillance mechanism is under way.

Disagreement surrounding linkages to the International Monetary Fund was appeased through negotiation of the Chiang Mai Initiative. The Initiative's use (as well as the flexibility) of soft law satisfied signatories, feeling that adaptations could be more easily made within the soft law agreement than with a hard law agreement. This flexibility convinced states opposed to IMF interference in the Asian region to sign an agreement containing IMF conditionality with future aspirations for renegotiation of the Initiative with more independence. The goal of the Asian neighbours to facilitate financial cooperation and prevent future crisis, as well as the consultative nature of the soft law agreement, overcame the hurdles and brought states in Asia to the negotiating table.

\section{EVOLVING FRAMEWORK}

The Asian Monetary Fund, as previously discussed, attempted to pave an independent road to financial cooperation for the region and was very vocal about its commitment to the 'Asian model of development,' which directly opposed the economic policies supported by

\footnotetext{
${ }^{88}$ After the production of this thesis, on April 4, 2007, ASEAN+3 finance officials announced an agreement to upgrade the Chiang Mai Initiative into a multilateral deal, moving into the "second phase" of financial cooperation in the East Asian region. In a Bangkok newspaper, The Nation, Wichit Chaitrong stated this move could pave the way for the establishment of a regional institution. "If the second phase is successful, the cooperation will enter the third stage where a central body will be established to manage international reserves and achieve the ultimate goal of an Asian Monetary Fund, providing immunity against volatility in the global financial market." Details on these developments were taken from, Wichit Chaitrong, "East Asian Finance Meeting: International reserves to be pooled", The Nation, April 5, 2007, sec. Business, < http://www.nationmultimedia.com/2007/04/05/business/business_30031123.php > [accessed on April 18, 2007]; AFP, "ASEAN to bolster defences a decade after Asian financial crisis", Channel NewsAsia, April 5, 2007, sec. Business, <http://www.channelnewsasia.com/stories/afp_asiapacific_business/view/268679/1/.html $>$ [accessed on April 18, 2007].
} 
the international financial institutions and major Western economies. Once such an institutional arrangement is created and granted legal legitimacy, its dismantling would prove to be very difficult. Thus, with an international financial institution already in place and the role of the newly proposed institution unclear, the international legal framework was not prepared to alter economic governance in this manner. Arguably, the AMF carried the necessary elements to aid Asian economies experiencing economic difficulty but failed because of not recognizing the necessity of any initiative to complement the international structure. Although the IMF does not enforce binding obligations upon its membership, the role of power politics and its institutional leadership position gives it great influence over economic developments (institutional or otherwise). Thus, it is necessary for any initiatives to adhere to the obligations of the international economic framework, in order to be granted legitimacy in the economic governance structure.

By not properly outlining the role of the AMF as a new institution in the economic governance structure, explaining future developments of the institution or working within the confines of the international legal framework for governing economic cooperation, the idea for the AMF was easily dismantled. But having noted its shortcomings, lessons were learned from the AMF and its failure helped in the success of future initiatives.

In attempting to succeed in an area where the AMF had failed, the Manila Framework Group may have gone too far the opposite way in terms of conforming to the international framework, previously established by the Asian Crisis as a flawed structure. To ensure alignment with and support from the international community, the Group includes international financial institutions and Western economies in its membership. The determination of the initiative not to be rejected is admirable and understandable after the 
shelving of the AMF, but ensuring its compatibility with the International Monetary Fund has resulted in its ineffectiveness. The Group does not work to facilitate financial cooperation, reach agreement on financial issues or further economic governance. It is currently an underdeveloped surveillance mechanism, which works mostly under the auspices of the IMF.

Regional initiatives in Asia began in order to avoid another financial crisis like the one that plagued them in $1997 / 1998$ as well as protect economies facing an economic downturn during such times. However, the Manila Framework Group serves only as a supplement to the IMF and does nothing to evaluate or reform the problems within the governance structure, which led to the Asian Crisis in the first place.

With the desire for financial cooperation in Asia on the rise, the Japanese Minister of Finance entered with a plan that found middle ground between rejection and ineffectiveness. The New Miyazawa Initiative appeased independence seekers in the East and the economic governance structure dominated by the West. The bilateral loans carried the same ideology of the international financial institutions and, like the IMF, promoted debt restructuring and repayment as an essential objective. In addition, because they were bilateral agreements and the establishment of an institution was not suggested, the Initiative in no way usurped or undermined the leadership of the International Monetary Fund. Stakeholders in the international community had no grounds to intervene in the bilateral agreements, suggest an approach or influence their content, and the much needed liquidity was provided with speed and was devoid of conditionalities. It was essentially a commitment made by the Japanese government, supplemented by a series of bilateral, soft law agreements with other regional economies. 
The New Miyazawa Initiative established an important foundation for financial cooperation in the region as it attempted to repair problems in economic governance while respecting the jurisdiction of the international legal framework already in place. Certainly, just as the New Miyazawa Initiative learned from the Asian Monetary Fund and Manila Framework Group proposals, the Chiang Mai Initiative learned from it and as a result of these developments, East Asia is entering an era of financial cooperation and changing the face of economic governance.

The Chiang Mai Initiative is a new and continuously developing framework that brings historical rivals into a regional partnership and has the support of the international community. The regionally pioneered Chiang Mai Initiative has defended issues surrounding its effectiveness, its relationship to the International Monetary Fund and its prospects for evolution, all of which are the very reasons for its success as it holds great prospects for the future.

The tie to the International Monetary Fund in developing supplementary surveillance procedures also appeases the international community and, in turn, can benefit the region. ${ }^{89}$ In a soft law agreement like the Chiang Mai Initiative, surveillance is tightly linked to compliance. In situations where there is no enforcement mechanism or third party dispute mechanism, well-developed surveillance allows the flow of information and knowledge regarding a partner's economic activities and compliance with the agreement.

\section{FUTURE POSSIBILITIES}

With the aforementioned Asian Crisis surprising East Asia, the international financial institutions and the international community, the need for improved surveillance among

\footnotetext{
${ }^{89}$ Yung Chul Park and Yunjong Wang, supra note 86, page 96.
} 
regional neighbours was demonstrated. The initiatives underway in East Asia recognize this problem and regional neighbours are working on their capacity to improve that situation to avoid future crises. Rana outlines how "efforts are being made to establish early warning systems and to monitor short-term capital flows. A study group has also been set up to identify a Monitoring or Surveillance Unit for the successful implementation of the CMI.",90 Such initiatives are developed to relieve international and regional concerns surrounding a future crisis and are one more step towards an established framework for economic governance in East Asia.

The possibilities for the evolution of the Chiang Mai Initiative are enormous. Predictions range from exchange rate regimes, to common currencies, to a full economic grouping likened to the European Union. Wang notes "the three pillars of liquidity assistance, monitoring and surveillance and exchange rate coordination are essential elements for regional financial and monetary cooperation." ${ }^{, 91}$ If these are the three pillars, then the Chiang Mai Initiative is well on its way to paving the road to unprecedented economic cooperation in East Asia. Already, the leg of liquidity assistance is established and serious discussion and research are being completed surrounding monitoring and surveillance processes. Expansion of, and cooperation with, the ASEAN Surveillance Process established in 1998 could cement the second leg, leaving only exchange rate coordination, which is also being studied as a definite possibility. ${ }^{92}$

While these possibilities are exciting for the development of regional financial cooperation, the opportunity most intriguing - for the purposes of this paper - is the legitimization of soft law through this Initiative. Already soft law is facilitating agreement-

${ }^{90}$ Pradumna B. Rana, supra note 77, page 11.

${ }^{91}$ Yunjong Wang, supra note 70, page 940.

92 Ibid. 
making in a largely unregulated finance sector. In addition, the foundation of soft rules for governing this financial aspect of the economy is likely to influence international initiatives, as parties attempting to regulate the sector look to existing soft rules or develop their own soft rules to govern behaviour. The regional success of soft law will naturally influence other agreements made as regulation of the finance sector develops.

Furthermore, the Chiang Mai Initiative represents an arrangement which could prove to the international community the developments that soft law can produce in governing economic relations more generally. The adherence, continued promotion and respect of the ASEAN +3 coalition to the Initiative can be seen as legitimizing soft law as part of economic governance and demonstrating its ability to facilitate agreement. As such regional initiatives evolve and eventually lead to and influence international agreements, their use of a soft law approach will surface as a model for governing the finance sector internationally and as a legitimate facet of international law. 
Chapter 4:

Implications for Economic Governance 
The Chiang Mai Initiative is altering the economic governance of the finance sector. Simultaneously, the Chiang Mai Initiative is introducing regional financial cooperation, facilitating agreements and can be seen as legitimizing soft law as a form of governance within international law.

When the Asian Crisis took the East Asian region and the world by storm in 1997, it highlighted serious flaws in economic governance as the market system contributed to the crisis and international financial institutions responded inappropriately. After the realization that the systems and institutions in place were unable to protect vulnerable economies and prevent or at least quell crisis, East Asia took steps and developed initiatives to protect itself; if the current structure could not help, they would create their own. They approached the task of dictating action in the finance sector cooperatively and the entire region - not just those in the midst of the crisis - discussed initiatives that would prevent another economic catastrophe. Some failed and some succeeded but the need to regulate this sector overcame the tedious negotiation process.

The latest arrangement, the Chiang Mai Initiative, fills the gaps left open in the current governance structure and is facilitating regulation of the finance sector with a soft law approach. This Initiative has no legal obligations, binding rules or dispute settlement mechanism but it is a viable arrangement. In a sector without an abundance of regulation and using an approach to governance not recognized as binding international law, East Asia developed a plan for addressing financial circumstances. This plan encompasses all nations in East Asia, but none are legally obligated to comply. They do comply for the benefits felt from cooperation and because they know all too well the consequences of not being prepared for crisis. With the poor track record of the international community and domestic 
economies' inability to stop a crisis, soft law is facilitating a regional initiative in Asia to help govern the finance sector. In return, the Chiang Mai Initiative can be seen as legitimizing the soft law approach to governance, which is facilitating this cooperation.

This chapter begins with a look at the weaknesses in economic governance - which led to the development of the Chiang Mai Initiative - and will discuss both international financial institutions and the market system. It will then outline the benefits of an evolving framework in economic governance and examine the implications of using a soft law approach in this developing framework. It will end with political considerations which may impede such initiatives but notes the strides made thus far, suggesting further developments are possible. This chapter outlines the problems in economic governance and demonstrates how an alternative model (a soft law approach) for governing the finance sector can produce results.

The Chiang Mai Initiative moves beyond simply bringing regulation to the finance sector, to consultatively create a legal framework and maintain cooperation in the absence of hard rules and binding obligations. Its use of soft law to govern the finance sector influences the way in which states negotiate economic priorities and carries implications for international relations, more generally, by expanding options for facilitating cooperation and creating international agreements.

With political will and economic ability, regional initiatives contributing to the economic framework are redefining governance in the finance sector and creating a prominent place for soft law in international relations. 


\section{WEAKNESSES IN ECONOMIC GOVERNANCE}

Reform of any framework or institution is usually only discussed after a failure has occurred within the system. A more evolutionary approach may avoid such systemic failure as it improves procedures through a continuous process of evaluation. By continuously examining weaknesses in the economic system and opening it up to alternative approaches to governance, financial crisis may be easier to avoid. Increasing the avenues for stability in the finance sector through the introduction of alternative approaches to governance, gives economies more opportunity to partner in order to monitor problematic issues, solves discrepancies found in economic systems and brings benefits to the overall governance structure.

International law may be slow, and often reluctant to change, and thus reform, its approach to governance, but weaknesses in the current economic governance structure cannot be ignored. Currently, economic governance fails to avoid, or even respond appropriately to economic crisis. If a governance structure cannot effectively govern, then reform is necessary in order for it to maintain legitimacy. Several elements of the international structure are proving to be unable to produce predictabaility and stability in the finance sector. During the Asian crisis, the International Monetary Fund (IMF) experienced issues with timeliness and policy content. ${ }^{93}$ This resulted in mistrust of the IMF in the region. It is not a positive reflection on economic governance when domestic economies lose faith in international financial institutions, whose purpose is to aid in their economic development. In addition, the crisis, itself, highlighted the debate between macroeconomic factors and eratic market

\footnotetext{
${ }^{93}$ Yongding Yu, supra note 72, page 5; "Regional Financial Cooperation in East Asia..." supra note 8, page 93.
} 
behaviour with investor panic holding at least part of the blame. ${ }^{94}$ With such doubt surrounding international financial institutions and market behaviour, the economic governance structure has serious evaluation to undertake and perhaps even lessons to learn from, not only the Asian Crisis, but the response to it as well.

\section{INTERNATIONAL INSTITUTIONS}

The International Monetary Fund's policy reforms that followed the financial epidemic in Asia did nothing to quell the crisis. According to many analysts, whether supporters or critics of the international financial institutions, the recommendations of the Fund further aggravated the situation. Complaints surrounded the late response, the misdiagnosis of the problem and the lack of consultation with the region concerning policy prescriptions and 'rescue' packages. The lack of flexibility in implementing the IMF's recommendations made matters worse as each nation had to conform to the suggestions in order to receive rescue funding at all. Indeed, the Asian Crisis - and the international response to it - outlined major weaknesses in the current economic governance structure. ${ }^{95}$

As in any emergency situation, most especially a financial crisis, the key is to respond quickly and accurately to the situation. Examining the onset of the Asian Crisis, when short term loans came due, investors demanded repayment and this reimbursement was guaranteed

\footnotetext{
${ }^{94}$ Robert Wade, “From 'miracle' to 'cronyism': explaining the Great Asian Slump", Cambridge Journal of Economics (November 1998) Vol 22, No 6, page 700.

${ }^{95}$ Information regarding the policy prescriptions of and action taken by the International Monetary Fund discussed in the "International Institutions" section of this chapter has been taken from the following illustrative list of sources: Walden Bello, "The End of a 'Miracle.' Speculation, Foreign Capital Dependence and the Collapse of the Southeast Asian Economies", The Multinational Monitor (January/February 1998) Vol 19, No 1 and 2; Robert Wade, "From 'miracle' to 'cronyism': explaining the Great Asian Slump", Cambridge Journal of Economics (November 1998) Vol 22, No 6; Joseph Stiglitz, "More Instruments and Broader Goals: Moving Towards the Post-Washington Consensus", UNU World Institute for Development Economics Research, 1998 Wider Annual Lectures (1998); Yung Chul Park and Yunjong Wang, "The Chiang Mai Initiative and Beyond", The World Economy (January 2005) Vol 28, No 1; Chalongphob Sussangkarn, "East Asian Monetary Cooperation", Thailand Development Research Institute $<$ http://www.info.tdri.or.th/reports/unpublished/chals.pdf $>$ [accessed on March 2, 2005].
} 
due to the insistence of the international financial institutions. Decisions had to be made quickly and measures implemented immediately. However, aid packages were not promptly dispersed. ${ }^{96}$ The negotiation of conditionalities created lag and prevented a timely response. ${ }^{97}$ This in turn worsened investor panic as money managers learned of the need for International Monetary Fund lending and the possible time lapse in refunding investments. ${ }^{98}$ According to $\mathrm{Yu}$, an immediate response from the international community could have made all the difference. He proposes that "if on the inception of the crisis a large-scale rescue package had been put in place promptly, the contagious crisis would have been avoided. ${ }^{\prime \prime 99}$ It does stand to reason that had the crisis at least appeared to be under control by the international financial institutions, investors may not have fled so swiftly from the rest of the region and with such vehemence.

Due to the fast movement of capital flows, the contagious effect of the pullout in East Asia, and the previous international response, a regional initiative may be optimal in detecting problems more quickly, immediately responding to crises situations and developing solutions more suited to the region. The interests neighbours hold in each other's economic viability contributes to the quality of response to any crisis and, as Wang points out, regional parallels can be a source of contagion but also a possibility for comfort and aid in a crisis situation.

The geographic proximity and economic similarities of these Asian countries prompted the withdrawal of foreign lending and portfolio investment, whereas differences in economic fundamentals were often overlooked. Hence, neighbours have an interest in helping to put out a fire (a financial crisis) before it spreads to them.

\footnotetext{
${ }^{96}$ Yongding Yu, supra note 72 , page 5

${ }_{97}$ Robert Wade, supra note 93, page 699.

${ }^{98}$ Ibid.

${ }^{99}$ Yongding $\mathrm{Yu}$, supra note 72 , page 5 .
} 
Contagion is geographically concentrated, so that a regional grouping for support is logical. ${ }^{100}$

If for no reason other than pure self-interest, the initiatives of neighbouring countries can work towards preventing or, at least, containing a financial crisis. A regional rescue arrangement carries the advantages of understanding local situations, reacting more quickly and pooling resources for more efficient and effective dispersal of funds.

One positive aspect of the Chiang Mai Initiative is the promise it brings of a quick response should crises occur. An untimely response by the International Monetary Fund during the crisis of 1997-1998, as discussed above, may have led to further problems for national economies injured in the investment stampede. The mobilization of liquidity through a previously negotiated arrangement speeds up that process and may ease a speculative reaction on the part of investors. As explained in the Bulletin on Asia-Pacific Perspectives,

The swift availability of liquidity, together with the exchange of information among member Governments on the size and origin of capital movements, helps in curbing currency speculation and in countering investors' herd behaviour, often observed when markets turn down. In this sense, it contributes to reducing the volatility of market sentiment. ${ }^{101}$

The Chiang Mai Initiative is providing a framework for cooperation and increasing stability in financial markets by ensuring a quick response to crisis. The late response of the International Monetary Fund to the previous crisis not only further aggravated the situation

\footnotetext{
${ }^{100}$ Yunjong Wang, supra note 70.

101 "Regional Financial Cooperation in East Asia..." supra note 8, page 93.
} 
but also caused skepticism in East Asia concerning the ability of the international financial institutions to adequately deal with a crisis in the region. ${ }^{102}$

Help did finally arrive from the International Monetary Fund and lender nations with packages totaling $\$ 1$ billion for the Philippines, $\$ 17.2$ billion for Thailand, $\$ 42.3$ billion for Indonesia and \$58.4 billion for Korea (US funds). ${ }^{103}$ Unfortunately, when financial assistance was received, it was accompanied by improper and inflexible recommendations for the circumstances affecting Asia at the time. ${ }^{104}$

The policy advice given by the International Monetary Fund was misdirected, to say the least. Unlike a traditional current account crisis, East Asia suffered from a capital account crisis, and the aid, whether monetary or in the form of policy advice, did not properly address the situation at hand. Robert Wade notes this point and goes on to state,

The IMF's interventions in Thailand, Indonesia and Korea have made things worse than need be. Misdiagnosing the problem as a macroeconomic BOP [balance of payments] problem rather than as a microeconomic debt deflation problem, and as a crisis of excess consumption rather than excess investment, it [the IMF] insisted on a domestic austerity package and on fundamental structural reforms in return for bailout funds. ${ }^{105}$

Thus, not only was assistance late in coming, it was also poor in content. Yet the assistance plan was mandatory to receive funds. Due to late funding and poor prescriptions, the aid provided by the international financial institutions only caused the economies already in crisis to suffer further.

A regional proposal such as the Chiang Mai Initiative may ease fears that should a crisis occur, neighbours or bilateral swap partners understand the environment in which an

102 "Regional Financial Cooperation..." supra note 8, page 94.

103 "Regional Financial Cooperation..." supra note 8.

${ }^{104}$ Robert Wade, supra note 93.

105 Ibid. 
East Asian economy operates. Sussangkarn welcomes a regional process and sees it as "an additional forum to highlight possible vulnerabilities from the perspectives of people who are more familiar with the realities facing various economies in the region."106

In the practice of moving capital, there are borrowers and there are lenders. Both need to share responsibility. To suggest otherwise, also suggests favouritism. In the case of Thailand, specifically, Sussangkarn notes,

While imprudent foreign borrowing was clearly to blame for the crisis, imprudent lending by creditors was equally at fault. This, together with some structural reform measures that had elements of a fire-sale strategy, led to a broad mistrust of the IMF from many elements in Thailand and within the region, with many claiming that the IMF program was more designed for the benefit of foreign interests rather than for Thailand's recovery. ${ }^{107}$

When Western investors demanded full repayment of their short-term loans, the economies of East Asia had no choice but to turn to the International Monetary Fund. ${ }^{108}$ There they found guaranteed returns and loan conditions beneficial to investors who were, at the very least, a part of the problem. Certainly, proper fiscal austerity demands as part of the problem, they share part of the blame. ${ }^{109}$ The continuing debate between the structure of the financial sector and investor behaviour in the Asian Crisis still creates tension because to place responsibility for the crisis on the speculative behaviour of financial markets brings into question the self-correcting mechanism of the market. In addition, to blame the IMF and its policy prescriptions creates doubt in international financial institutions. Admission of a faulty market system and faulty international financial institutions by the international community

\footnotetext{
${ }^{106}$ Chalongphob Sussangkarn, supra note 85 , page 3.

${ }^{107}$ Chalongphob Sussangkarn, supra note 85 , page 13.

${ }^{108}$ Robert Wade, supra note 93, page 699.

${ }^{109}$ With Chalongphob Sussangkarn noting how both imprudent foreign borrowing and imprudent lending by creditors was equally at fault, (see note 106) it would seem only fair in the realm of international relations and global governance that all factors contributing to the problem would take responsibility for their part in creating it as well as pay restitution and make appropriate reforms to ensure the problem does not occur again.
} 
would cripple the economic governance structure and cast doubt upon its effectiveness and thus its legitimacy.

\section{FINANCIAL MARKETS AND ECONOMIC STRUCTURE}

The division of responsibility between the structure and maturity of domestic economies in East Asia and the behaviour of financial markets and their money managers is important when attempting to develop a legal framework for financial markets. It will necessarily impact the legitimacy of cooperation among nations within the region and also guide the creation of any framework dealing with international markets and capital flows.

The Asian Crisis brought to the forefront a debate surrounding macroeconomic fundamentals and investor panic camps. As Rana explains,

According to the former, the crisis resulted from weak macroeconomic fundamentals; in other words, it was a question of solvency. The competing view held that the crisis was an outcome of self-fulfilling prophecies and financial panics, including bank runs and outflow of hot money, because of structural weaknesses in financial and governance systems. ${ }^{10}$

The applicability of these two views of the Asian Crisis is important to distinguish where the problems lie within the financial system of Asian economies. It is generally accepted that the liberalization of financial markets in some Asian nations was premature and this allowed capital to flow at will in search of the best returns. ${ }^{111}$ With the scent of financial difficulties

\footnotetext{
${ }^{110}$ Pradumna B. Rana, supra note 77 , page 2.

111 Authors contributing to the debate surrounding premature financial market liberalization include Robert Wade, "From 'miracle' to 'cronyism': explaining the Great Asian Slump", Cambridge Journal of Economics (November 1998) Vol 22, No 6; Pradumna B. Rana, "Monetary and Financial Cooperation in East Asia: The Chiang Mai Initiative and Beyond", Asian Development Bank: Working Paper No 6 (February 2002); Christopher R. Way, "Political Insecurity and Financial Market Liberalization", Paper prepared for the 2002 Annual Meetings of the American Political Science Association, Department of Government, Cornell University, Ithaca, NY <http://www.international.ucla.edu/cms/files/Christopher_Way.pdf $>$ [accessed on February 20, 2007].
} 
in the air, these investors fervently withdrew their capital and called in their loans before they incurred any loss. In addition, the enormous amount of capital flowing into East Asia should have garnered attention and assistance from the international financial institutions long before it did, as there were well known problems surrounding deficits and currency devaluation in some economies. ${ }^{112}$ However the consensus during this time was that East Asia was a model for development. ${ }^{113}$ The Asian economies were producing expected returns and had done so for a substantial period prior to the crisis. With no one in the international community worried about the economic indicators in East Asia, it appears the speculative nature of investment was the cause of the disaster. This is not to say that reforms were not needed in certain economies, it simply outlines how herd-like behaviour facilitates a crisis. Robert Wade, stating the viability of the Asian economies, points the finger at the herd.

The crisis was caused in large part by speculator and investor pullout from economies that but for the pullout would have remained viable enough to generate returns within the normal range. The panic was not simply the "trigger" or the messenger of a crisis. The panic was a primary cause. ${ }^{114}$

For years, even decades, the Asian economies were held up as models for development and their 'fundamentals' were cited as sound, laying the groundwork for economic growth and prosperity. ${ }^{115}$ It took one crisis, one year, for that story to be turned around completely and, according to financial market critics, without speculative behaviour on the part of investors and money managers the story may have stayed the same.

\footnotetext{
${ }^{112}$ Robert Wade, supra note 93, page 697.

${ }^{113}$ This consensus was exemplified in reports from international financial institutions. See, for example, World Bank, The East Asian Miracle: Economic Growth and Public Policy (Washington D.C.: World Bank, 1993) and various World Bank annual reports including World Bank, World Development Report 1985 (Washington D.C.: World Bank, 1985).

${ }_{114}^{11}$ Robert Wade, supra note 93, page 703.

${ }^{115}$ World Bank, World Development Report 1985 (Washington D.C.: World Bank, 1985) notes these "economic policy reforms" and states that the "fastest growing [economies] were the East and South Asian countries", pages 6,18 , and 23 .
} 
The speculative nature of markets cannot be controlled by domestic economies no matter their level of development and the international community does not always respond appropriately to market failure. This leaves a major flaw in the economic governance structure, a flaw not being addressed by domestic or international initiatives. Because individual nations have little power to quell widespread crisis in their own, as well as neighbouring economies, and the response of the economic governance structure has been so weak in the past, a regional legal framework is being developed in East Asia to help control such volatile circumstances and environments. The creation of which can be seen as reforming the face of economic governance, a structure with severe structural weaknesses, a structure in grave need of reform.

\section{DEVELOPING GOVERNANCE IN ASIA}

Domestic governments are powerless to prevent or control a widespread financial crisis and the international framework has also failed in this regard. In addition, the international framework has failed to reform despite the structural weaknesses demonstrated by the Asian Crisis. Thus, partners in East Asia view regional initiatives as the optimal avenue to produce change in the economic governance structure in order to prevent and appropriately respond to crisis. Due to a multitude of factors, which include a culturally diverse group of signatories and a regional history of relations-based governance, regional developments are using a soft law approach. In this way, establishing a framework for regional financial cooperation in Asia carries huge implications for soft law. As East Asia cooperates to facilitate governance in a largely unregulated sector, which approach to governance they choose to implement will influence regulation of the finance sector as it 
develops in other regions and on a global basis. Thus, a regional framework not only

addresses problems in economic governance but lays the foundation for the legitimization of soft law as a source of governance within international law. With soft law playing such a prominent role in regional financial cooperation, it is sure to have a place in international agreements as regulation of the sector moves to global initiatives.

Cooperation in the East Asian region, like many initiatives surrounding international relations, is making a move towards a more rules-based approach to governance. However, these Asian partners are expanding the accepted definition of rules-based governance as they bring their relations-based history into developing regional initiatives for governing the finance sector. As the Chiang Mai Initiative demonstrates, a less obligatory approach to cooperation in the finance sector is facilitating agreement among historic rivals, establishing liquidity options for nations facing economic turmoil and creating stability in the region as investors' fears are quelled by the presence of readily available aid should problems arise.

In addition, regional cooperation can work to complement the international legal system. Other aspects of the international economic structure allow for coordination between international and regional arrangements as the World Trade Organization (WTO) demonstrates. ${ }^{116}$ The debate between multilateral and regional approaches to governance is a continuous one and certainly the preference of the international financial institutions (the WTO included) is a multilateral approach. ${ }^{117}$ Having said that, supporters of regional

\footnotetext{
${ }^{116}$ Pradumna B. Rana, supra note 77.

${ }^{117}$ The multilateral approach to agreement-making was supported by trade ministers representing member countries in "Where next for the WTO? After Cancun: Views, ideas and proposals by trade ministers", Federal Trust for Education and Research and Commonwealth Business Council (dated 2003) $<$ http://www.fedtrust.co.uk/uploads/FedT_CBC_Compendium.pdf $>$ [accessed on February 28, 2007]. In addition, the WTO officially states its "pursuit of an equitable, liberal and open rules-based multilateral trading system" in "The multilateral trading system in support of Africa-led and Africa-owned development", The World Trade Organization (dated July 16, 2001)

$<$ http://www.wto.org/english/news_e/spmm_e/spmm68_e.htm> [accessed on February 28, 2007].
} 
initiatives argue that allowing, and even facilitating their development can benefit international trading endeavours. Surely then a similar opportunity exists for regional financial cooperation. As Rana points out,

Regional trading arrangements are increasingly being seen as building blocks rather than stumbling blocks for an integrating world. Some 170 regional trading arrangements including bilateral areas have been registered with the WTO...There is no evidence suggesting that an East Asian financial arrangement will be oriented toward a withdrawal from the global economy and hence erect barriers to global financial integration. ${ }^{118}$

The International Monetary Fund itself supports regional cooperation as long as it remains in line with the international structure. The former IMF Managing Director, Horst Kohler, stated in 2001, "Our advice is to pursue regionalization, not in opposition to the IMF, because the IMF is a global institution, but to do it in a complimentary fashion. That is exactly what is happening now and it makes a lot of sense." 119

The support or opposition of the international community does play a role in furthering or constraining reform of the governance structure for financial markets in East Asia. A country is bound by its obligations to the international structure and when initiatives appear at odds with the international legal framework, the probability of their success is reduced significantly. Opposition from the International Monetary Fund and the United States blocked the idea for an Asian Monetary Fund due to the view it would attempt to replace the existing international legal structure. This exemplifies the necessity for compatibility among international and regional initiatives and depicts the role of the international framework in constraining regional proposals. However, as the trading regime

\footnotetext{
${ }^{118}$ Pradumna B. Rana, supra note 77.

119 "Focusing the Fund On Financial Stability", Far Eastern Economic Review (June 14 2001), page 49.
} 
has shown, regionalization can be compatible, even beneficial, to an international structure and there is no reason to assume those lessons cannot be transferred to the financial sector.

The developing initiatives in the region have built upon one another, learning from previous mistakes as well as taking past successes and expanding upon them to create a working governance structure. The region has explored a vast array of options in financial cooperation, ranging from regional institutions to bilateral agreements outside the purview of international economic law. Using a soft law approach to governance, current financial cooperation in the region remains faithful to the Asian way of negotiation ${ }^{120}$ while incorporating international requirements and thus maintains its legitimacy as a developing governance model for the finance sector and economic relations in general.

The economic disaster of 1997-1998 has led to cooperation within East Asia as nations attempt to create a financial framework to avoid such crises in the future. The Asian Crisis greatly impacted all of East Asia and when such a regional problem arises, regional responses naturally should, and do, occur. The fact that the regional responses utilize soft law to facilitate financial cooperation, find support from the international community and address the problematic issues within economic governance, indicate that a new and progressive method for governing economic activity is developing in East Asia. As regulation of such activity expands globally, soft law can have a significant role to play in reforming definitions of governance. It is currently facilitating financial cooperation in East Asia, changing the face of economic governance and laying the groundwork for a move to the international sphere.

${ }^{120}$ Soft law, as discussed in Chapter 2, relies heavily on consultation and negotiation, both of which are also highlighted in the "Asian way of negotiation" (defined in "Relations-based Governance" in Chapter 2). 


\section{POLITICAL CONSIDERATIONS}

The link between politics and law is difficult, if not impossible to break. ${ }^{121}$ Certainly, if the political will is not present to create economic cooperation, it is unlikely to develop. A discussion of the political constraints within Asia, as well as within the international community, is necessary to determine the viability of financial cooperation and through this cooperation, the legitimization of soft law. Thus, before we can discuss the future of regional economic cooperation and the impact its soft law approach will have in reforming economic governance more broadly, we must tackle some political considerations as political will determines the evolution of any framework, including one governing economic activity.

Though Japan is the most advanced economy in the region, the historical rivalry between China and Japan helped to quell the development of the Asian Monetary Fund and became an enormous blockage in the discussion of regional leadership. ${ }^{122}$ Once one steps outside the region, the political persuasion of the International Monetary Fund and the United States becomes very important as they maintain that the international system takes precedence over regional cooperation. ${ }^{123}$ These are not small hurdles to jump over, however, the progress thus far lends to the theory that governments within East Asia are, at the very least, willing to try.

\section{INSIDE THE REGION}

Japan is seen as an obvious economic leader in the East Asian region with the second largest economy in the world. It has also led the way in promoting economic cooperation

\footnotetext{
${ }^{121}$ Judith L. Goldstein et al, supra note 58, page 3.

${ }_{122}^{122}$ Yongding Yu, supra note 72, page 4.

123 "Focusing the Fund On Financial Stability", supra note 118.
} 
within the region as is demonstrated by their proposals for the Asian Monetary Fund, the New Miyazawa Initiative as well as their promotion of and participation in the Chiang Mai Initiative. The geographically small northern state contributed enormously to the economic recovery of its neighbours during the Asian Crisis as is noted by $\mathrm{Yu}$.

It should be recognized that since the early stage of the Asian financial crisis, the Japanese government played a leading role in providing funds for the rescue packages organized by the IMF. Japan's contribution of US $\$ 19$ billion far surpassed any other country's contribution. According to the Ministry of Foreign Affairs of Japan, during the Asian financial crisis, the total amount of financial assistance provided in various forms by Japan reached US $\$ 80$ billion. $^{124}$

As is evident from the amount of their foreign reserves compared with the rescue funding lent during the Asian Crisis, ${ }^{125}$ Japan almost has the single-handed ability to save the region from future crisis. They have demonstrated their willingness to use this ability in order to safeguard smaller economies from financial disaster for the good of the nation in crisis, the region and ultimately itself. For these reasons, there are those who would support Japan's leadership in any framework for future economic cooperation in East Asia. The other power in the region, however, poses a problem for a Japanese-dominated system.

The historical rivalry between Japan and China led China to reject the idea of an Asian Monetary Fund headed by Japan and continues to pose problems for the development of future initiatives. ${ }^{126}$ Arguably, the AMF was dismantled primarily because of the opposition from the International Monetary Fund and the United States but it is important to

\footnotetext{
${ }^{124}$ Yongding Yu, supra note 72 , page 4.

${ }^{125}$ See "International Institutions" section earlier in this chapter. Funding amounts taken from, "Regional Financial Cooperation in East Asia: The Chiang Mai Initiative and Beyond", Bulletin on Asia-Pacific Perspectives $<$ http://www.unescap.org/pdd/publications/bulletin2002/ch8.pdf $>$ [accessed on March 2, 2005], page 93 .

${ }^{126}$ Yongding $\mathrm{Yu}$, supra note 72.
} 
explain that the excitement surrounding the Asian Monetary Fund was not shared by all nations within the region. China was less than enthusiastic for several reasons. First of all, China was caught by surprise with the introduction of this proposal and was also suspicious of Japan's intentions, demonstrating the problems in the relationship between China and Japan. Second, China was not convinced of the need for a regional fund as they had a relatively good relationship with the International Monetary Fund. Third, China was unsure of the benefits it would incur from such an initiative, and questions surrounding national sovereignty arose within the country. Fourth, China was basically unaffected by the Asian Crisis with the biggest fallout coming from decreased exports, which was seen as an international market issue. ${ }^{127}$ While China has since stated its commitment to regional cooperation, at that time, Yongding notes, "China's attention was focused on global solutions," due to the aforementioned factors. ${ }^{128}$ China's support of any regional initiative being developed in Asia is important as it grows into an economic powerhouse in the global economy and they are backing the Chiang Mai Initiative with great political will.

The leadership issue is a major setback in the evolution of a regional framework as each nation has its own interests, ideas, and faults which question their desirability as heads of an evolving system. Park and Wang point out,

China and Japan are expected to provide leadership in forging regional consensus for expanding and consolidating the BSAs as a regional institution, but they have not been able to agree on a number of operational issues including the surveillance mechanism. This concern appears to be the most serious roadblock to further development of the CMI. ${ }^{29}$

\footnotetext{
${ }^{127}$ Yongding Yu, supra note 72 , page 4.

${ }^{128}$ Ibid.

${ }^{129}$ Yung Chul Park and Yunjong Wang, supra note 86, page 98.
} 
The difficulties of cooperation should not, however, overshadow the possible benefits each could receive through cooperation, nor should it negate the strides that have been made thus far. The signing of bilateral swap arrangements between the two nations exemplifies that consensus can be reached among the states and according to Shaun Narine, China has warmed up to the idea of a regional fund and pledges full support for the endeavour. ${ }^{130}$ Regionalism has brought together historic rivals in Europe and there is no reason to doubt the possibilities for those same developments in Asia. Stevenson points out,

The European process of unification included a treaty of peace and friendship between Germany and France. They then led that process. Japan and China have a common interest in cooperation. Japan's recovery depends on East Asia. Their interests are complimentary. Regionalism could bring them closer together. ${ }^{131}$

Japan and China, to date, have made great strides towards cooperation and with successful and evolving initiatives in the works there is reason to be optimistic. Their cooperation is essential in the development of regional initiatives and thus in the furthering of a soft law approach to governance but soft law is facilitating this cooperation where hard law may have hindered agreements between these two Asian economic giants. Thus, the irony lies within soft law's need for cooperation between Japan and China to legitimize it as a valid governance approach while the two nations have been brought to the bargaining table due to flexibility and lack of binding obligations in soft law.

One of the difficult considerations for financial integration in the region is China's focus on trade as its most important economic pursuit. ${ }^{132}$ China was not greatly impacted by

\footnotetext{
${ }^{130}$ Shaun Narine, supra note 74, page 258.

${ }^{131}$ Adlai E. Stevenson, "Regional financial cooperation in Asia", Journal of Asian Economics (October 2004) Vol 15, Issue 5, page 839.

${ }^{132}$ Yongding Yu, supra note 72, page 4.
} 
the Asian Crisis beyond a reduction in the demand for exports. ${ }^{133}$ With the financial crisis several years in the past and trade liberalization at the forefront, financial cooperation in China may be usurped by trade interests. However, the gains from financial integration can only serve to compliment trade interests, which have already been highly developed. Also, increased cooperation is aimed at preventing future crises and speculative attacks which benefits the region as a whole in areas where individual and global tactics have been unsuccessful in the past. Agarwala and Prakash contend,

The marginal contribution from further trade liberalization alone is likely to be small and extended over a long period. More immediate and larger gains are likely to be achieved by closer financial cooperation in the region to reduce the vulnerability of the region to internal and external shocks. To tackle these problems, neither individual country efforts nor the current global efforts are sufficient. ${ }^{134}$

Therefore, regionalization could yield higher returns and will almost certainly increase the possibility for future trade relations and general economic prosperity by bringing stability and predictability to East Asia and, to a larger extent, international financial markets. In addition, the implications these regional initiatives hold for economic governance as a whole undoubtedly impact China and offer yet another reason for the Asian state to support such initiatives.

\section{OUTSIDE THE REGION}

The international sphere is of the utmost importance for the International Monetary Fund and the United States, who both have a great influence on any regional effort within East Asia or any other part of the world. Their interests lie within the primacy of the

\footnotetext{
${ }^{133}$ Ramgopal Agarwala and Brahm Prakash, supra note 79, page 2.

${ }^{134}$ Ibid.
} 
international economic system as a whole and they are cautious about the perceived threat to that system brought about through regional initiatives in Asia. The debate surrounding the Asian model of development is in essence a battle between the neo-liberal economic system and a more embedded market system supplemented by industrial policy and state intervention, a method used in some of the economically successful Asian nations. ${ }^{135}$ This was part of the debate surrounding the Asian Monetary Fund and continues to surface in the discussion of financial cooperation in East Asia. As Yu explains,

The United States would not talk about international monetary reform, because a superpower never pushes international monetary reform unless it sees reform as a change to break up a threat to its own hegemony. From a national standpoint, the United States is never going to suggest an alternative to its present system because it is already a system where the United States maximizes its seigniorage. East Asia should and would not tolerate this situation forever. ${ }^{136}$

The issue then becomes how to present a soft law approach to regional cooperation as beneficial to the global economy and actors in the economic system. Any arrangement involving the creation of stability and predictability in East Asia will have positive spillovers for the global economy and for international financial markets. In order to overcome the international superiority hurdle, East Asia must fashion cooperation in such a way that global advantages are prominently displayed and promoted.

In developing this latest proposal for economic cooperation in East Asia, the constraints imposed by the global governance structure were carefully examined and addressed in the Chiang Mai Initiative. Due to the failure of past ideas such as the Asian Monetary Fund, compliance with the international structure is an integral part of this

\footnotetext{
${ }^{135}$ World Bank, The East Asian Miracle: Economic Growth and Public Policy (Washington D.C.: World Bank, 1993), page 24.

${ }^{136}$ Yongding $\mathrm{Yu}$, supra note 72 , page 8.
} 
initiative. The tie to IMF conditionality for the full realization of loans under the Chiang Mai Initiative has allowed the evolution of the East Asian proposal and the constraints of the existing legal framework must be continuously accounted for in future developments. The opposition of some nations to any loan conditionality from the International Monetary Fund holds the possibility of creating tension between the existing structure and the development of a new legal framework. ${ }^{137}$ The key to easing such stress may lie in the evolution of the bilateral loan agreements and the establishment of a more institutionalized approach to stabilizing the financial sector. If East Asia can develop a framework in which, as neighbours, there is enough power and influence to ensure the realization of agreed to stipulations and the repayment of loans without an overarching international structure, then they may be able to achieve the independence nations like Malaysia demand. The solution lies in molding this framework so that it appeases and supports nations of the region and still meets the obligations associated with an international legal framework. The Chiang Mai Initiative can, and perhaps should be, interpreted as just the beginning and its importance lies within the possibilities it presents for the future.

The political implications for the development of a legal framework are perhaps the largest of East Asia's issues in promoting regional cooperation. In the creation of such a structure there are important economic and social factors which must be taken into account but these seem to have been overcome, for the most part, at this stage in the evolution of regional initiatives. The political element remains, however. Any framework purporting a deviation from the international structure thus runs the risk of being denied. Indeed it would appear as though creating a new legal framework (or reforming the current legal framework)

\footnotetext{
${ }^{137}$ The opposition of states such as Malaysia to loan conditionality is noted by, Yung Chul Park and Yunjong Wang, supra note 86.
} 
is needed but one cannot be created unless it is complementary to the existing structure, a structure which has not proven itself able to deal with crisis situations. This dichotomy is perhaps the largest hurdle in developing a new legal framework and in attempting to reform global governance in any substantial way.

The constraints imposed by the international legal framework greatly impact the development of regional proposals but are not necessarily a barrier to it. The progress made with the Chiang Mai Initiative demonstrates the ability of international and regional interests to coincide and now that framework building has begun and progress has been made, demolition of these ideas is unlikely to occur. Compatibility between an international and regional structure appears to be achievable despite the political factors outlined above. And for those seeking independence, the example of the European Union and the political, economic and social barriers faced in the development of that framework is a historical precedent that can be followed; an independent, socially-oriented union, operating completely within the confines of an international legal framework. This carries major implications for economic governance as soft law regional initiatives develop and alter the international structure governing the finance sector. 
Chapter 5:

Conclusion 
There are weaknesses in the current economic governance structure and these weaknesses warrant reform of the framework for governing economic relations. The potential of the Chiang Mai Initiative and its soft law approach to governance addresses these problems. This carries implications for global governance and international relations as a whole and may alter our current classifications of law and governance. While there are political considerations to tackle, the desire for cooperation in the development of the Chiang Mai Initiative has overcome them thus far and there is no reason to doubt that this desire will remain. The Chiang Mai Initiative is set on a course to establish regional agreements as a viable asset in governing financial markets and its soft law approach may bring nonbinding cooperation in line with binding regulation, which will inevitably alter economic governance as it is currently defined.

The Asian Crisis was a shock to the East Asian region, the international financial institutions and the international community. It highlighted the volatility of financial markets and the vulnerability of domestic economies to financial shocks. Most importantly it illustrated the inability of the economic governance structure to quell crises and restore stability to regional economies severely damaged by the stampede of capital. The current global financial architecture fails to address the problems of free market capital flows and is unable to adequately deal with crises and repair the damage caused by the unrestrained speculative nature of financial markets. Due to issues of timeliness, appropriateness of policies and willingness to collaborate, the current international legal framework has not proven able to control or predict financial market behaviour. This is a serious gap in the governance mechanism for regulating economic activity. A gap which can be filled with the development of a regional legal framework set up to address the problematic issues in the 
international system. Thus, neighbouring states in East Asia have taken it upon themselves to establish a legal framework in order to bring stability and predictability to the region. The capability of the East Asian region to develop such a framework is apparent and the strides made among those nations to cooperate, while working to compliment the international structure, illustrate the desire that accompanies that ability.

The Chiang Mai Initiative holds much promise for East Asian nations in this endeavour as it addresses the failures of the international framework and has the support of the international community. In addition, it is using a soft law approach to governance in order to facilitate cooperation in the finance sector. The regional framework for governing this sector has very low levels of obligation, precision and delegation; it contains no legally binding rules, no repercussions for withdrawal from the Initiative and no formal dispute settlement mechanism. It relies on mutual benefits gained from cooperation to maintain adherence to the arrangement. The benefits of stabilizing financial markets and maintaining the economic viability of all partners in the region are felt by all the Asian neighbours in the same way the repercussions of crisis impact each signatory in some fashion.

The Chiang Mai Initiative brings nations in East Asia to the table to promote financial cooperation. Some of these nations have a troubled history. Most of them come from backgrounds with different legal and cultural preferences. Thus, while rules-based governance provides a sense of security among strangers in that a framework outlines actions and behaviour, a soft law rules-based approach provides the flexibility needed to come to specific arrangements. Because the finance sector is not heavily regulated by international financial institutions or international agreements, like many other aspects of economic governance, the movement being made in the area of financial cooperation in East Asia is an 
astounding development and carries huge implications for international financial cooperation and the role soft law will play in economic governance. Its success can be seen as carrying with it a legitimizing effect for a soft law approach to governance as regional initiatives governing the finance sector expand globally.

The ability of soft law to facilitate cooperation among the East Asian nations demonstrates the power of this approach to governance. As governance of the almost unregulated finance sector develops, soft law will continue to play a significant role in the governing of this sector due to its prevalence in the conception of current initiatives. As the Chiang Mai Initiative develops, so will the place of soft law in economic governance.

Attempting to include, as well as exclude, soft law from becoming a legitimate source of governance within international law are both political strategies. Choosing to use or not use soft law when creating agreements is yet another political strategy. One political strategy becomes the dominating ideology in global governance due to the fact that international law itself has a geo-political bias and it is that biased legal framework which bestows legitimacy when two political strategies are competing for legal validation in the international sphere. Having said that, when two strategies have proven their ability to produce beneficial results, it is the responsibility of the international community to open its legal toolbox and bestow legitimacy upon these policies and upon international law itself by removing any biases within it.

The generally accepted definition of governance has often involved regulation but East Asia's preference for a consultative approach to governance has expanded the understanding of regulation to include soft law as a legitimate approach to governing the finance sector. It has offered an alternative option to sectors uncomfortable with hard rules 
and legal obligations. Since soft law has been the central instrument in facilitating the governance of financial markets in East Asia, it is certain to maintain this influence as regulation of the sector continues. As governance of financial markets develops to a global level, the soft law approach, originating from regional financial cooperation, may naturally evolve into a legitimate facet of international law and influence international relations. More importantly, the impact a less legalized approach is having on governing financial markets, carries into other sectors of the economy and global governance in general. This will not negate the role of hard law in international transactions, but it does open international relations to alternative approaches to agreement, bring more parties to the negotiation table and produce cooperative arrangements. Introducing more methods for cooperation can only prove to benefit economic governance and international relations as a whole. 


\section{$\underline{\text { Bibliography }}$}

Abbott, Kenneth W. and Duncan Snidal. "Hard and Soft Law in International Governance." International Organization. (2000) Vol 54, No 3.

Abbott, Kenneth W., Robert O. Keohane, Andrew Moravcsik, Anne-Marie Slaughter, and Duncan Snidal. "The Concept of Legalization." In Judith L. Goldstein, Miles Kahler, Robert O. Keohane, Anne-Marie Slaughter, eds. Legalization and World Politics. Cambridge: MIT Press. May 2001.

AFP. "ASEAN to bolster defences a decade after Asian financial crisis." Channel NewsAsia. April 5, 2007. Sec. Business.

$<$ http://www.channelnewsasia.com/stories/afp_asiapacific_business/view/268679/ 1/.html $>$ [accessed on April 18, 2007].

Agarwala, Ramgopal and Brahm Prakash. "Regional Cooperation in Asia: Long-term Progress, Recent Retrogression, and the Way Forward." Asian Development Bank: ERC Working Paper Series No 28. (October 2002).

"Basel Committee on Banking Supervision," Risk Glossary $<$ http://www.riskglossary.com/articles/basle_committee.htm>.

Bello, Walden. 'The End of a 'Miracle.' Speculation, Foreign Capital Dependence and the Collapse of the Southeast Asian Economies." The Multinational Monitor. (January/February 1998) Vol 19, No 1 and 2. <http://www.hartfordhwp.com/archives/54/124.html $>$ [accessed on February 25, 2005].

Chaitrong, Wichit. "East Asian Finance Meeting: International reserves to be pooled." The Nation. April 5, 2007. Sec. Business. $<\mathrm{http}: / /$ www.nationmultimedia.com/2007/04/05/business/business_30031123.php > [accessed on April 18, 2007].

Chayes, Abram and Antonia Handler Chayes. The New Sovereignty: Compliance with International Regulatory Agreements. Cambridge: Harvard University Press, October 1998.

Chinkin, C. M. "The Challenge of Soft Law: Development and Change in International No. 4.

Law." The International and Comparative Law Quarterly. (October 1989) Vol. 38,

Commission on Global Governance. Our Global Neighbourhood. New York: Oxford University Press, 1995. 
D'Amato, Anthony and Kristin Engel. International Environmental Law Anthology. Ohio: Anderson Publishing Company, 2001. $<$ http://anthonydamato.law.northwestern.edu/IELA/Intech05-2001-edited.pdf $>$ [accessed on November 3, 2006].

"Dispute Settlement." Foreign Affairs and International Trade Canada. (last updated November 11, 2006) <http://www.dfait.maeci.gc.ca/tna-nac/dispute-en.asp > [accessed on November 16, 2006].

Dixit, Avinash. "Lawlessness and Economics: Alternative Modes of Economic Governance." Gorman Lectures - University College, London. (December 2002) $<$ http://www.econ.ucl.ac.uk/downloads/Lec1.pdf $>$ [accessed November, 29 2005].

Doyle, Michael W. "Liberalism and World Politics." The American Political Science Review. (December 1986) Vol. 80, No. 4.

"Focusing the Fund On Financial Stability." Far Eastern Economic Review. June 14, 2001.

Franck, Thomas M. "Fairness in International Law and Institutions." Gloucestershire: Clarendon Press. January 1998.

Gavin, Caroline and Rebecca Stuart. "Regulatory Developments in the Capitalisation of Banks - A Financial Stability Prespective." Financial Stability Report. (2005).

Gold, Joseph. "Strengthening the Soft International Law of Exchange Agreements." The American Journal of International Law. (1983) Vol 77, No 3.

Goldstein, Judith L., Miles Kahler, Robert O. Keohane, Anne-Marie Slaughter. "Introduction: Legalizations and World Politics." International Organization. (2000) Vol 54, No 3.

Hakim, Peter. “Is Latin America Doomed to Failure?" Foreign Policy. (Winter, 1999/2000) No. 117.

Harvey, David. A brief history of neoliberalism. Oxford, New York: Oxford University Press, 2005.

Hendy, Peter. "Engaging Asia." Australian Chamber of Commerce and Industry, Faculty of Asian Studies - Australian National University (August 15, 2004) $<$ http://www.acci.asn.au/text_files/speeches_transcripts/2004/Engaging\%20Asi $\% 20$ Speech\%20-15\%20August\%202004.pdf $>$ [accessed on February 28, 2007].

Henning, C. Randall. East Asian Financial Cooperation. Washington, D.C.: Institute for International Economics. September 2002. 
Hillgenberg, Harmut. “A Fresh Look at Soft Law." Economic Journal of International Law. (1999) Vol 10, No 3.

"Indepth: Softwood Lumber Dispute." (dated August 23, 2006)

$<$ http://www.cbc.ca/news/background/softwood_lumber/ $>$ [accessed on November $16,2006]$.

Jackson, John H. "Editorial Comment: The WTO Dispute Settlement Understanding Misunderstandings on the Nature of Legal Obligation." American Journal of International Law. The American Society of International Law (January 1997) Vol 91, No 60.

"Regional Financial Cooperation among ASEAN+3." Japan Ministry of Finance. $<$ http://www.mof.go.jp/english/if/regional_financial_cooperation.htm $>$ [accessed on January 24, 2007].

Johnston, Douglas M. "Commitment and Compliance: The Role of Non-Binding Norms in the International Legal System." The American Journal of International Law. (2001) Vol 95, No 3.

Jolly, Richard Louis Emmerji and Thomas G Weiss. "The Power of UN Ideas: Lessons from the First 60 years." New York: United Nations Intellectual History Project Series. (May 2005) <http://www.unhistory.org/UNIdeas.pdf $>$ [accessed on February 20, 2007].

Kahler, Miles. "Legalization as Strategy - The Asia-Pacific Case." International Organization. (2000) Vol 54, No 3.

Kaminsky, Graciela L. and Carmen M. Reinhart. "Banking Crises, Currency Crises, and Macroeconomic Uncertainty: Financial Crises in Asia and Latin America: Then and

Now." The American Economic Review. Papers and Proceedings of the Hundred and Tenth Annual Meeting of the American Economic Association. $\quad$ (May 1998) Vol 88, No. 2 .

Kennedy, David. "New Approaches to Comparative Law: Comparativism and International Governance." (1997) Utah Law Review. Issue 545.

King, Michael R., and Timothy J. Sinclair. "Private Actors and Public Policy: A Requiem for the New Basel Captial Accord." International Political Science Review. (2003) Vol 24, No 3.

Koh, Harold Hongju. "Why Do Nations Obey International Law?" The Yale Law Journal. (1997) Vol. 106, No. 8.

Krahmann, Elke. "National Regional, and Global Governance: One Phenomenon or Many?" (2003) Global Governance. Vol 9. 
Lopez-Santana, Mariely. "Introduction." University of Michigan. Comparative Speaker Series.

$<$ http://sitemaker.umich.edu/comparative.speaker.series/files/chapter1_sept_16.pdf $>$ [accessed on November 17, 2006].

Lorenz, Edward. "Deterministic Nonperiodic Flow." Journal of Atmospheric Sciences. (March 1963) Vol 20, No 2.

"Memorandum for Chief Executive Officiers." The Office of Thrift Supervision. Department of Treasury. (1989) <http://www.ots.treas.gov/docs/2/25135.pdf $>$ [accessed on January 24, 2007].

"Miyazawa Initiative wraps up, providing \$21 bil". Asian Economic News. (March 6, 2000)

$<$ http://www.findarticles.com/p/articles/mi_m0WDP/is_2000_March_6/ai_59998149 $>$ [accessed on February 27, 2007].

Moore, Patrick. "Current Development: The Decisions Bridging the GATT 1947 and the WTO Agreement." American Journal of International Law. The American Society of International Law. (April 1996) Vol 90, No 317.

Narine, Shaun. "ASEAN and the Idea of an 'Asian Monetary Fund." The $2^{\text {nd }} A S E A N$ Reader. Compiled by Sharon Siddique and Sree Kumar. Singapore: Institute of Southeast Asian Studies. 2003.

Ocampo, José Antonio. "The Role of Regional Institutions." In Jan Joost Teunissen, eds. A Regional Approach to Financial Crisis Prevention: Lessons from Europe and Initiatives in Asia, Latin America and Africa. The Hague: FONDAD. November 2002. $<\mathrm{http}$ ://www.fondad.org/publications/regional/Fondad-Regional-ApproachBookComplete.pdf $>$ [accessed on February 20, 2007].

Park, Yung Chul and Yunjong Wang. "The Chiang Mai Initiative and Beyond." The World Economy. (January 2005) Vol 28, No 1.

Peng, Shin-yi. "The WTO Legalistic Approach and East Asia: From the Legal Culture Perspective." Asian-Pacific Law and Policy Journal. (2000) Vol 1, Issue 2.

Plumptre, Tim. "What is Governance?" Institute on Governance $<$ http://www.iog.ca/page.asp?pageID=3\&HTMLAREA=HOME $>$ [accessed on February 28, 2007]. 
President Tadao Chino. "Monetary and Financial Cooperation in East Asia: Lessons from Europe." Remarks at the 4th ASEAN Finance Ministers' Meeting. Copenhagen, Denmark. (5 July 2002)

$<$ http://www.adb.org/Documents/Speeches/2002/ms2002073.asp $>$ [accessed on March 2, 2005].

Radelet, Steven, Jeffrey D. Sachs, Richard N. Cooper, Barry P. Bosworth. "The East Asian Financial Crisis: Diagnosis, Remedies, Prospects." (1998) Brookings Papers on Economic Activity. Vol. 1998, No. 1.

Rana, Pradumna B. "Monetary and Financial Cooperation in East Asia: The Chiang Mai Initiative and Beyond." Asian Development Bank: Working Paper No 6. (February 2002).

Reich, Arie. "From Diplomacy to Law: The Juridicization of International Trade Relations." Journal of International Law and Business. (Winter 1996/Spring 1997) Vol 17, No 2/3.

"Regional Financial Cooperation in East Asia: The Chiang Mai Initiative and Beyond." Bulletin on Asia-Pacific Perspectives. $<$ http://www.unescap.org/pdd/publications/bulletin2002/ch8.pdf $>$ [accessed on March 2, 2005].

Roett, Riordan and Russell Crandall. 'The Global Economic Crisis, Contagion, and Institutions: New Realities in Latin America and Asia." International Political Science Review (July 1999) Vol. 20, No. 3.

Shuhe Li, John. "Relations-based versus Rule-based Governance: an Explanation of the East Asian Miracle and Asian Crisis." Review of International Economics. (2003) Vol 11 , Issue 4.

"Softwood Lumber." Export and Import Controls. Foreign Affairs and International Trade Canada. (Last updated October 11, 2006)

$16,2006]$.

$<$ http://www.international.gc.ca/eicb/softwood/intro-en.asp $>$ [accessed on November

Stevenson, Adlai E. "Regional financial cooperation in Asia." Journal of Asian Economics. (October 2004) Vol 15, Issue 5.

Stewart, Ian. Does God Play Dice? The Mathematics of Chaos. London, England: Penguin Books, 1997.

Stiglitz, Joseph. "More Instruments and Broader Goals: Moving Towards the PostWashington Consensus." UNU World Institute for Development Economics Research. (1998) 1998 Wider Annual Lectures.

Sussangkarn, Chalongphob. "East Asian Financial Cooperation: An Assessment of the 
Rationales." Thailand Development Research Institute.

$<$ http://www.info.tdri.or.th/reports/published/po8.pdf $>$ [accessed on March 2, 2005].

Sussangkarn, Chalongphob. "East Asian Monetary Cooperation." Thailand Development

Research Institute. <http://www.info.tdri.or.th/reports/unpublished/chals.pdf $>$ [accessed on March 2, 2005].

Thakur, Ramesh, and Thomas G. Weiss. The UN and global governance: an idea and its prospects. Bloomington, IN: Indiana University Press. 2006.

"The multilateral trading system in support of Africa-led and Africa-owned development." The World Trade Organization (dated July 16, 2001) $<$ http://www.wto.org/english/news_e/spmm_e/spmm68_e.htm> [accessed on February 28, 2007].

Trubek, David, Patrick Cottrell and Mark Nance. "“Soft law,' 'Hard law,' and European Integration: Toward a Theory of Hybridity." NewGov: New Modes of Governance (dated February 2006) <http://www.eunewgov.org/database/DELIV/DLTFIaD03b_European_Integration_Toward_a_Theor y_of_Hybridity.pdf $>$ [accessed on January 8,2007 ].

Truman, Edwin M. "Introduction and Summary." In Reforming the IMF for the $21^{\text {st }}$ Century Edwin M. Truman eds. Institute for International Economics, Special Report 19. (April 2006) $<\mathrm{http}: / /$ www.iie.com/publications/chapters_preview/3870/01iie3870.pdf $>$ [accessed on February 28, 2007].

"Understanding the WTO: Settling Disputes. A unique contribution," World Trade Organization. <http://www.wto.org/english/thewto_e/whatis_e/tif_e/disp1_e.htm> [accessed on December 20, 2006 and February 9, 2007 (after re-design)].

Wade, Robert. "From 'miracle' to 'cronyism': explaining the Great Asian Slump." (November 1998) Cambridge Journal of Economics. Vol 22, No 6.

Wang, Yunjong. "Financial Cooperation and Integration in East Asia." Journal of Asian Economics. (October 2004) Vol 15, Issue 5.

Way, Christopher R. "Political Insecurity and Financial Market Liberalization." Paper prepared for the 2002 Annual Meetings of the American Political Science Association. Department of Government, Cornell University. Ithaca, NY. $<$ http://www.international.ucla.edu/cms/files/Christopher_Way.pdf $>$ [accessed on February 20, 2007].

"What is the IMF?" International Monetary Fund (dated September 30, 2006) $<$ http://www.imf.org/external/pubs/ft/exrp/what.htm> [accessed on February 28, 2007]. 
"Where next for the WTO? After Cancun: Views, ideas and proposals by trade ministers." Federal Trust for Education and Research and Commonwealth Business Council (dated 2003) < http://www.fedtrust.co.uk/uploads/FedT_CBC_Compendium.pdf $>$ [accessed on February 28, 2007].

World Bank. The East Asian Miracle: Economic Growth and Public Policy. Washington D.C.: World Bank. 1993.

World Bank. World Development Report 1985. Washington D.C.: World Bank. 1985.

Yu, Yongding. "On East Asian Monetary Cooperation." Institute of World Economics and Politics: Chinese Academy of Social Sciences. $<$ http://www.iwep.org.cn/pdf/02wp_rcif.pdf $>$ [accessed on March 2, 2005]. 